\title{
Avalanches and micrometeorology driving mass and energy balance of the lowest perennial ice field of the Alps: a case study
}

\author{
Rebecca Mott $^{1,2}$, Andreas Wolf ${ }^{3}$, Maximilian Kehl ${ }^{1}$, Harald Kunstmann ${ }^{1,4}$, Michael Warscher ${ }^{1,4,5}$, and \\ Thomas Grünewald ${ }^{2}$ \\ ${ }^{1}$ Institute of Meteorology and Climate Research, Atmospheric Environmental Research (KIT/IMK-IFU), \\ KIT-Campus Alpin, Garmisch-Partenkirchen, Germany \\ ${ }^{2}$ WSL Institute for Snow and Avalanche Research SLF, Davos, Switzerland \\ ${ }^{3}$ Institute for Karst and Cave Science, Germany \\ ${ }^{4}$ Institute of Geography, University of Augsburg, Augsburg, Germany \\ ${ }^{5}$ Department of Geography, University of Innsbruck, Innsbruck, Austria
}

Correspondence: Rebecca Mott (mott@slf.ch)

Received: 19 November 2018 - Discussion started: 5 December 2018

Revised: 28 February 2019 - Accepted: 27 March 2019 - Published: 15 April 2019

\begin{abstract}
The mass balance of very small glaciers is often governed by anomalous snow accumulation, winter precipitation being multiplied by snow redistribution processes (gravitationally or wind driven), or suppressed snow ablation driven by micrometeorological effects lowering net radiation and/or turbulent heat exchange. In this case study, we analysed the relative contribution of snow accumulation and ablation processes governing the long- and short-term mass balance of the lowest perennial ice field of the Alps, the Ice Chapel, located at $870 \mathrm{~m}$ a.s.l. in the Berchtesgaden National Park (Germany). This study emphasizes the importance of the local topographic setting for the survival of a perennial ice field located far below the climatic snow line. Although long-term mass balance measurements of the ice field surface showed a dramatic mass loss between 1973 and 2014, the ice field mass balance was rather stable between 2014 and 2017 and even showed a strong mass gain in 2017/2018 with an increase in surface height by $50 \%-100 \%$ relative to the ice field thickness. Measurements suggest that the winter mass balance clearly dominated the annual mass balance. At the Ice Chapel surface, $92 \%$ of snow accumulation was gained by snow avalanching, thus clearly governing the 2017/2018 winter mass balance of the ice field with mean snow depths of $32 \mathrm{~m}$ at the end of the accumulation period. Avalanche deposition was amplified by preferential deposition of snowfall in the wind-sheltered rock face surrounding the ice field.
\end{abstract}

Detailed micrometeorological measurements combined with a numerical analysis of the small-scale near-surface atmospheric flow field identified the micrometeorological processes driving the energy balance of the ice field. Measurements revealed a katabatic flow system draining down the ice field throughout the day, showing strong temporal and spatial dynamics. The spatial origin of the thermal flow system was shown to be of particular importance for the ice field surface energy balance. Numerical simulation indicates that deep katabatic flows, which developed at higher-elevation shaded areas of the rock face and drained down the ice field, enhance sensible heat exchange towards the ice field surface by enhancing turbulence close to the ice surface. Conversely, the shallow katabatic flow developing at the ice field surface appeared to laterally decouple the local near-surface atmosphere from the warmer adjacent air suppressing heat exchange. Numerical results thus suggest that shallow katabatic flows driven by the cooling effect of the ice field surface are especially efficient in lowering the climatic sensitivity of the ice field to the surrounding rising air temperatures. Such micrometeorological phenomena must be taken into account when calculating mass and energy balances of very small glaciers or perennial ice fields at elevations far below the climatic snow line. 


\section{Introduction}

Very small glaciers are especially sensitive to climatic changes and are considered to be strong climate indicators. Most of the world's smaller glaciers will disappear by 2100 (Radić and Hock, 2011). In the Swiss Alps, $90 \%$ of the glaciers have areas of less than $1 \mathrm{~km}^{2}$ (Paul et al., 2004). Similar distributions have been observed for other mountainous regions (Glazirin, 1985; Dickich and Hagg, 2004; Bahr and Radic, 2012; Kuhn et al., 2012). Their high number makes them significant contributors to the regional and global hydrological cycle (Bahr and Radic, 2012) as well as to sealevel rise (Radić and Hock, 2011). Thus, it is crucial to understand the mass balance of very small glaciers and its climatic drivers. Although very small glaciers are especially vulnerable to changing air temperatures due to their small altitudinal extension (Müller, 1988), a large number of very small glaciers and perennial ice fields are known to exist far below the climatic snow line. The reason for their existence was often found to be anomalous accumulation, winter precipitation being multiplied by wind drift (Dadic et al., 2010), preferential deposition of snow (Mott et al., 2014, 2018; Gerber et al., 2017, 2019), or avalanches (Kuhn, 1995). Not only snow accumulation in winter, but also regional climate (Mölg et al., 2009; Kaser et al., 2004), convective cloud formation (Nicholson et al., 2013), or micrometeorological effects lowering the incoming solar radiation or changing the turbulent heat exchange (Denby and Greuell, 2000; Escher-Vetter, 2002; Oerlemans and Van Den Broeke, 2002; Petersen et al., 2013) were found to be driving factors for the survival of very small glaciers and perennial ice fields. The sensitivity of melt rates to temperature change is determined by changes in longwave radiation balance and turbulent heat fluxes (Oerlemans, 2001; Ayala et al., 2015). While the effects of katabatic flows on the mass and energy balance of large glaciers have been intensively investigated (Kuhn, 1995; Oerlemans and Grisogono, 2002; Strasser et al., 2004; Shea and Moore, 2010; Ayala et al., 2015), katabatic flow development over perennial ice fields and large snow patches (Mott et al., 2015, 2017, 2018) has gained little attention so far. Experimental and numerical studies on the energy balance of perennial ice fields and large snow patches (Marsh and Pomeroy, 1996; Essery et al., 2006; Fujita et al., 2010; Mott et al., 2011, 2013, 2016; Curtis et al., 2014; Schlögl et al., 2018a, b) identified additional micrometeorological processes strongly affecting the local air temperature and associated heat exchange processes, such as cold-air pooling, boundary layer decoupling, and advective heat transport. These processes are also expected to be important climatic drivers for the mass balance of very small glaciers by strongly affecting their sensitivity to an increase in ambient air temperature. Considering the effect of micrometeorological drivers, as well as processes promoting strong amplifications of solid precipitation over very small glaciers (e.g. cirque glaciers) and perennial ice fields, will help to improve the assessment of climate change impacts on very small glaciers, representing the majority of the glaciers in the Alps.

The climatic snow line, which is the line above which snow will remain all year, is about $2500-2800 \mathrm{~m}$ above sea level (a.s.1.) for the northern slopes of the Alps with a median snow line for the entire Alps of $3083 \pm 1121 \mathrm{~m}$ (Hantel et al., 2012). The lowest perennial ice field of the Alps, the Ice Chapel, is located at approximately $870 \mathrm{~m}$ a.s.l., which is far below the local and the alpine climatic snow line. The existence of the perennial ice field is assumed to be attributable to extreme snow accumulation in winter due to avalanches and preferential deposition of precipitation in the wind-sheltered area surrounding the ice field. We assume that the topographic setting of the Ice Chapel further involves micrometeorological effects on snow ablation such as strong topographic shading and the development of thermal flow systems. This study is the first attempt to address snow accumulation and ablation processes affecting the mass and energy balance of the Ice Chapel, located in the Berchtesgaden National Park.

We present data on the long-term areal change of the ice field between 1973 and 2018. Mass balance measurements in 2017/2018 allowed us to investigate the winter and summer surface change in very high spatial resolution. Based on those data we estimate the relative contribution of avalanching and precipitation to the winter snow accumulation at the perennial ice field. We further discuss the contribution of micrometeorology on the summer mass balance of the Ice Chapel by experimentally and numerically investigating the flow field development and associated small-scale air and surface temperature variations at the Ice Chapel and its surroundings. The respective results are discussed and summarized at the end of the paper.

\section{Methods}

\subsection{Study area}

The Berchtesgaden National Park is located in the Bavarian Alps at the border between Germany and Austria $\left(47.552778^{\circ}, 12.975833^{\circ}\right)$ and comprises an area of $208 \mathrm{~km}^{2}$. Within this area, the landscape ranges between 501 and $2713 \mathrm{~m}$ a.s.l. The perennial ice field, the Ice Chapel, is located in the interior of Berchtesgaden National Park (Germany) at the upper end of the Eisbach valley (Fig. 1). Located at an elevation between approximately 870 and $1100 \mathrm{~m}$ a.s.l., approximately $1000 \mathrm{~m}$ below the regional tree line and well below the actual climatic snow line at the northern slopes of the Alps (approximately $2500-2800 \mathrm{~m}$ ), the Ice Chapel is the lowest perennial ice field of the Alps (Hornauer and Eichner, 1997; Wolf, 2007; Rödder et al., 2010). The perennial ice body is surrounded by the steep rock walls of the Watzmann massif $(2713 \mathrm{~m})$. The Watzmann east face is on average $51^{\circ}$ inclined and some parts of the rock face show slopes above 


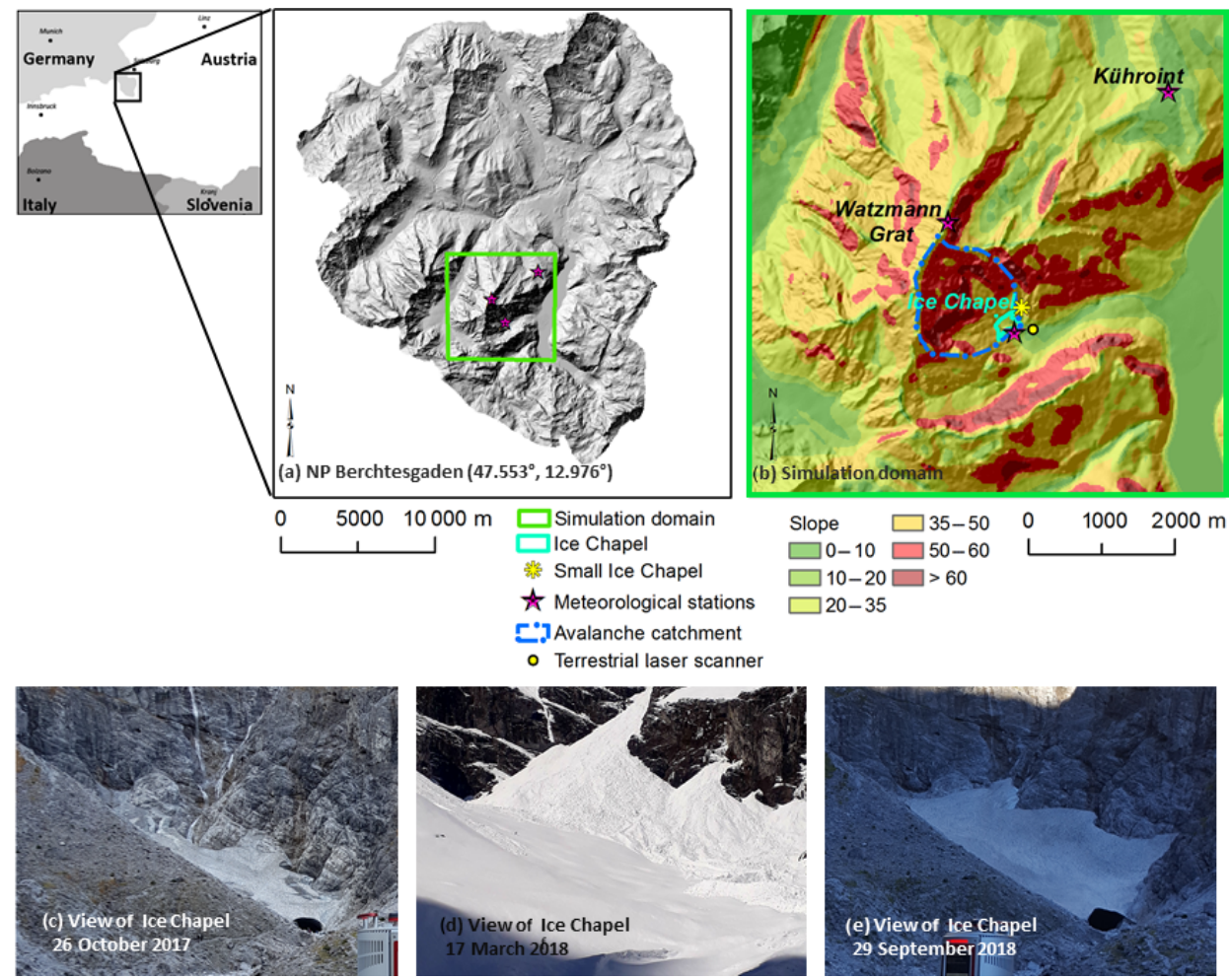

Figure 1. (a) Hillshade of Berchtesgaden National Park. (b) Slope of topography shown for the simulation domain for atmospheric modelling. Meteorological stations (stations met), the location of the large Ice Chapel and small Ice Chapel, and the catchment of avalanches potentially accumulating at the large Ice Chapel are presented. (c, d, e) View of the Ice Chapel from the east in October 2017 from the location of terrestrial laser scanner installation on 26 October 2017 (c), on 17 March 2018 (d), and on 29 September 2018 (e).

$70^{\circ}$ (Fig. 1). Due to its steepness and its funnel-shaped configuration, the rock face surrounding the Ice Chapel constitutes an avalanche release area of $1.6 \mathrm{~km}^{2}$ with avalanches accumulating in the angle of the rock face, where the Ice Chapel is located. The Ice Chapel is bordered by the rock face to the north-west and two moraines to the north-east and south-west. We refer to moraines as any rocks that have been moved in, on top of, or under the ice field or have been deposited close to it. The small Ice Chapel (Fig. 1) is located north-east of the large Ice Chapel and is also fed by avalanches in winter. Contrary to the large Ice Chapel, the small Ice Chapel totally disappeared in some years of low snow accumulation.

\subsection{Remote-sensing measurements}

\subsubsection{Mass balance measurements}

High-resolution surface measurements were conducted with a terrestrial laser scanner (TLS; Riegl VZ-6000) on 26 October 2017, 17 March 2018, and 29 September 2018 in order to obtain winter and summer mass balance of the Ice Chapel.

The second summer mass balance measurements were performed in late September since a snowfall event was forecasted for early October. Since the Ice Chapel receives nearly no shortwave radiation in autumn (Fig. 2), no strong ablation was expected for October.

In past studies, repeated TLS was successfully applied to calculate snow volumes (Grünewald et al., 2018; Grünewald and Wolfsperger, 2019) or snow depth changes during the accumulation (Mott et al., 2010; Schirmer et al., 2011; Sommer et al., 2015) and ablation season (Grünewald et al., 2010; Egli et al., 2012; Mott et al., 2011; Schlögl et al., 2018a) with a vertical accuracy of less than $10 \mathrm{~cm}$ for a $300 \mathrm{~m}$ distance (e.g. Prokop et al., 2008; Revuelto et al., 2014). A more general description of the TLS measurement set-up and accuracy over snow can be found in Prokop et al. (2008), Schaffhauser et al. (2008), and Grünewald et al. (2010). To reduce scan shadows the laser scanner was set up at up to three different positions. The area of the Ice Chapel and its surroundings was then recorded with a frequency of $300 \mathrm{kHz}$ and angular step widths between 0.002 and 0.05 depending on maximum measurement distance, which ranged from 300 to $500 \mathrm{~m}$. We followed the post-processing procedure described by Grünewald et al. (2018) and Grünewald and Wolfsperger (2019). First coarse registration was performed using small reflector plates mounted in the area and/or topographic features (such as well-defined rocks) as tie points. This registration was then improved by applying a 3-D-surface match- 


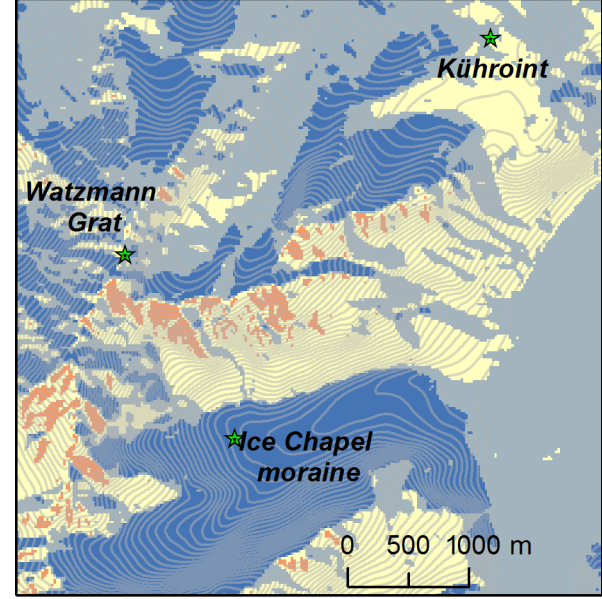

26 October 2017 12:00 CEST

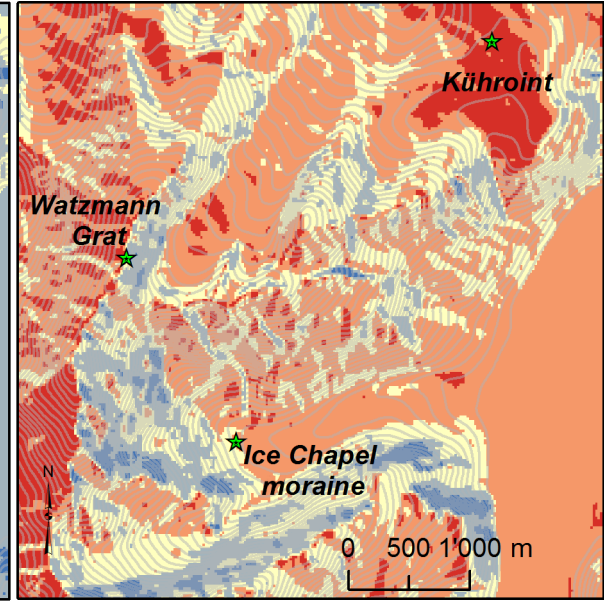

19 July $201812: 00$ CEST

\footnotetext{
Shortwave solar radiation (clear sky) $\left(\mathrm{W} \mathrm{m}^{-2}\right)$

$\square<100 \square 500-700$

$\square 100-300 \quad \square>700$
}

Figure 2. Potential shortwave radiation for 26 October 2017, 12:00 and for 19 July 2018, 12:00.

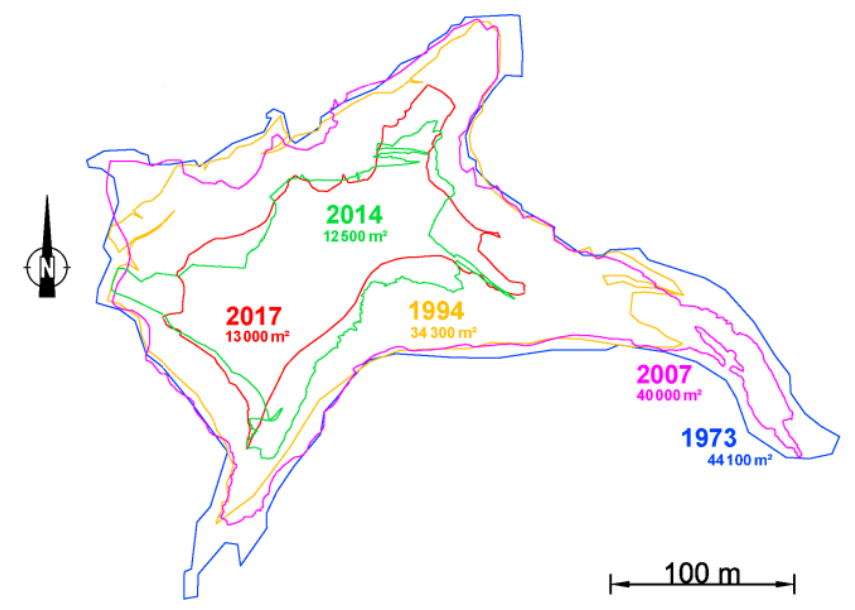

Figure 3. Minimum surface area of the Ice Chapel measured at the end of the ablation season (October) of the respective year.

ing function (multi-station adjustment; Riegl Laser Measurement Systems GmbH, 2011). In the following, the data were transformed to a global coordinate system (UTM). Finally, data amounts were reduced by aggregation of the point clouds to $25 \mathrm{~cm} 3$-D grids (octree filter) and raster of surface change (cell size $0.5 \mathrm{~m}$ ) was calculated in ArcMap 10.2.

\subsubsection{Estimation of aerial changes since 1973}

The spatial extent of the Ice Chapel was assessed using different remote-sensing measurement techniques. The accuracy and point density of each measurement device is summarized in Table 1. The technological progress has al- lowed for a change from point measurements retrieved from tachymetry (1994) to high-resolution 3-D scans of the surface using TLS (since 2007).

Aerial photos (WILD RC7) generated in autumn 1973 allowed for the retrieval of the spatial extent of the Ice Chapel surface with a high accuracy of $0.1 \mathrm{~m}$. Aerial stereo image pairs were assessed with mechanical optical autographs (WILD, A4). In 1994, a geodetic network was created in the western part of the upper Eisbach valley basin in the surroundings of the Ice Chapel and connected to the national surveying network. In autumn 1994, an engineering theodolite and reflector lot were used to retrieve the surface of the Ice Chapel, complemented with field sketches. Using tachymetry, the position $(x)$ and altitude $(y)$ of several points of the surface were measured with an accuracy of $0.01 \mathrm{~m}$ in both directions. In autumn 2007, measurements of the Ice Chapel surface were conducted combing tachymetry (Leica, TCRA 1101) and terrestrial laser scanning (Leica, HDS2500). Further tie points were installed at the Ice Chapel surface and surveyed with tachymetry and transformed to the national surveying network. The TLS allowed for the first time the assessment of the ice field surface with a much higher spatial resolution (point density of $0.1 \mathrm{~m}$ for $100 \mathrm{~m}$ measurement distance) and with a higher measurement accuracy of $0.005 \mathrm{~m}$. Following the same procedure as in 2007, the Ice Chapel surface was surveyed in autumn 2014 using a Faro scanner (FOCUS3 DX130) and a Leica theodolite (TCRA 1200) and in autumn 2017 using a total station Trimble (SX10) and a TLS (Riegl VZ-6000). In autumn 2018, surface measurements were conducted with the Riegl VZ-6000 as described above. 
Table 1. Overview of remote-sensing measurements applied at the Ice Chapel since 1973.

\begin{tabular}{|c|c|c|c|c|c|}
\hline $\begin{array}{l}\text { Time of } \\
\text { measurement }\end{array}$ & Measurement technology & Device & $\begin{array}{l}\text { Accuracy } \\
x, y \\
(\mathrm{~m})\end{array}$ & $\begin{array}{l}\text { Point } \\
\text { density } \\
(\mathrm{cm})\end{array}$ & $\begin{array}{l}\text { Measured } \\
\text { surface } \\
\text { area }\left(\mathrm{m}^{2}\right)\end{array}$ \\
\hline September 1973 & $\begin{array}{l}\text { Photogrammetric analysis of } \\
\text { aerial photos }\end{array}$ & WILD RC7 & $0.1^{\mathrm{a}}$ & & 44100 \\
\hline October 1994 & Tachymetry & Theodolite WILD, TC 1610 & $0.01^{\mathrm{a}}$ & & 34300 \\
\hline \multirow[t]{2}{*}{ July 2007} & Tachymetry & $\begin{array}{l}\text { Theodolite Leica, TCRA } \\
1101\end{array}$ & $0.01^{\mathrm{a}}$ & & 40000 \\
\hline & Terrestrial laser scanning & Leica, HDS2500 & $0.005^{\mathrm{a}}$ & $10^{\mathrm{b}}$ & \\
\hline \multirow[t]{2}{*}{ November 2014} & Terrestrial laser scanning & FARO, FOCUS3 DX130 & $0.005^{\mathrm{a}}$ & $6.14^{b}$ & 12500 \\
\hline & Tachymetry & $\begin{array}{l}\text { Theodolite Leica, TCRA } \\
1200\end{array}$ & $0.01^{\mathrm{a}}$ & & \\
\hline \multirow[t]{3}{*}{ October 2017} & Terrestrial laser scanning & $\begin{array}{l}\text { Total station TRIMBLE, } \\
\text { SX10 }\end{array}$ & $0.005^{\mathrm{a}}$ & $12.28^{b}$ & 13000 \\
\hline & Terrestrial laser scanning & Riegl VZ 6000 & $0.015^{\mathrm{a}}$ & $2^{\mathrm{b}}$ & \\
\hline & Tachymetry & Total station Trimble, SX10 & $0.01^{\mathrm{a}}$ & & \\
\hline September 2018 & Terrestrial laser scanning & Riegl VZ 6000 & $0.015^{\mathrm{a}}$ & $2^{b}$ & \\
\hline
\end{tabular}

a According to manufacturer information for specific measurement set-ups. ${ }^{\mathrm{b}}$ Values are given for $100 \mathrm{~m}$ measurement distance.

\subsection{Meteorological measurements: air temperature and surface temperature measurements}

The spatial variability of near-surface air temperatures in the region of the Ice Chapel was captured measuring air temperatures at 20 locations using four mobile meteorological stations SnoMoS (Pohl et al., 2014). We simultaneously measured air temperature and humidity at $2 \mathrm{~m}$ above the surface with mobile towers on 26 October 2017 between 12:00 and 13:00 (CEST, for all times in this paper), along three transect lines: (1) the lower part of the Ice Chapel and adjacent slope of the north-easterly moraine, (2) the downstream region of the Ice Chapel snout, and (3) on top of the south-westerly moraine. Directly over the Ice Chapel, only two measurements were possible due to safety reasons. Measured air temperatures are $10 \mathrm{~min}$ averages. One station was installed over the entire measurement period of $1 \mathrm{~h}$ at one location further downstream to take into account the temporal evolution of air temperature. Air temperature at this location was rather constant during the measurement period, varying by less than $1{ }^{\circ} \mathrm{C}$.

A thermal infrared camera (IR camera hereafter), VarioCAM HD research 900 (InfraTec $\mathrm{GmbH}$ ), was used to measure surface temperatures at the Ice Chapel area with a high spatial and temporal resolution. The camera uses an uncooled microbolometer array for the detection of thermal infrared radiation in the spectral range of $7.5-14 \mu \mathrm{m}$. The resolution of the camera is $1024 \times 768$ pixels with a measurement range from -40 to $1200{ }^{\circ} \mathrm{C}$ and an accuracy of $\pm 1.5 \mathrm{~K}$ for the measurement range. Measurements were conducted during $2 \mathrm{~d}$ with partly cloudy conditions (12 and 13 July 2018) and 2 d with clear sky conditions (19 and 20 July 2018). Highresolution data were acquired on an hourly basis from 09:00 until 17:30. The camera position slightly moved over the course of three measurement days due to instabilities of the tripod, making an analysis of the temporal evolution of single pixels unfeasible. Since the presence of clouds significantly influenced the spatial variability of surface temperatures during 13 July, we focus the analysis on days with clear sky conditions.

No meteorological data are available at the Ice Chapel area during the IR measurements. We only analyse the spatial variability of surface temperatures $\left(T_{\mathrm{S}}\right)$ over the same surface type (rock and debris; excluding ice surface) and the change of patterns over time. We are thus only interested in relative temperatures and not in absolute surface temperatures. We also limit the analysis to single profile lines of rather small distances of tens of metres in order to minimize differences in measurement errors due to not applying atmospheric corrections. In an earlier study (Mott et al., 2017), a comparison of relative temperatures obtained from the IR camera used here, a CNR4 sensor and a mobile weather station showed that relative values coincide well, mainly not exceeding the arbitrary threshold of $\pm 0.5 \mathrm{~K}$. Since our analysis is limited to relative changes in surface temperatures in space and time, we do not apply corrections for the emissivity of the different 
Table 2. Measurement campaigns conducted in 2017 and 2018.

\begin{tabular}{ll}
\hline $\begin{array}{l}\text { Measurement campaigns } \\
2017 / 2018\end{array}$ & Measurements \\
\hline 26 October 2017 & TLS, mobile meteorological stations \\
17 March 2018 & TLS \\
12, 13, 19, 20 July 2018 & IR measurements \\
29 September 2018 & TLS \\
\hline
\end{tabular}

surfaces and the atmospheric transmissivity, which mainly affect absolute values or relative values for very large areas with strongly varying distances. The dynamics of air flow is derived from the change in surface temperatures along transect lines crossing the north-easterly moraine adjacent to the lower part of the Ice Chapel and crossing the south-westerly moraine at the outflow region of the Ice Chapel snout (see Fig. 9). Each transect line represents the average values of five neighbouring pixels.

\subsection{Atmospheric modelling of near-surface boundary layer development}

An atmospheric model Advanced Regional Prediction System (ARPS) was applied to simulate the atmospheric flow field in the region of the Watzmann massif, including the area of the Ice Chapel. Flow fields were calculated on a horizontal resolution of $20 \mathrm{~m}$, on a domain covering the entire Watzmann massif (Fig. 1). The simulations use 60 vertical terrain-following levels. The vertical resolution of the first grid above surface ranges between 1.4 and $2.6 \mathrm{~m}$ with an average value of approximately $2 \mathrm{~m}$ at the Ice Chapel area.

We used a small integration time step of $0.01 \mathrm{~s}$ and an acoustic wave mode with a time step of $0.001 \mathrm{~s}$. Flow fields were calculated for 19 July (measurement campaign in 2018) and 26 October (measurement campaign in 2017) reflecting two different situations regarding the exposure of the rock face and the Ice Chapel to shortwave radiation. While most of the simulation area is exposed to the sun during the day in July, it becomes shaded during most of the day in October (Fig. 2). Simulations start at 12:00 UTC and were run for an integration time of $3600 \mathrm{~s}$. We chose noon because approximately peak radiative forcing should highlight the difference in boundary layer development between the two different situations in the ablation season. The results on boundary layer development and heat exchange processes are a snapshot in time and do not cover the temporal variability in turbulent fluxes of heat and momentum that is connected to large eddies. Running the model over an entire day generates numerical stability problems which are likely related to insufficient vertical resolution when shallow stable atmospheric layers develop (Mott et al., 2015). Results of Raderschall et al. (2008) could evidence fully developed turbulent flow field characteristics after an integration time of about 600 and $3600 \mathrm{~s}$ when running idealized simulations with ARPS using a similar domain size, model resolution, and a small integration time step of $0.01 \mathrm{~s}$.

Air temperature and wind velocity measurements are only available in a high spatial resolution in the area of the Ice Chapel on 26 October. For model initialization, meteorological data from three stations have been considered: permanent weather station Watzmann Grat $(1635 \mathrm{~m})$, permanent weather station Kühroint (1420 m), and mobile meteorological stations at the moraine close to the Ice Chapel (900 m). Air temperatures obtained from the stations Kühroint, Watzmann Grat, and the mobile station at the moraine ice suggest two different model set-ups to analyse the flow field development for July and October: (1) slightly stable atmospheric conditions for October simulations (Väisälä frequency $N \approx 0.01 \mathrm{~s}^{-1}$ ) and (2) neutral atmospheric conditions for July simulations, using measured air temperatures from stations at different elevations. The first set-up is considered to reflect the situation of strong shading of the lower part of the east face of the Watzmann massif and no solar radiation in the area of the Ice Chapel over the entire day favouring stable atmospheric conditions. The second setup reflects a situation of a mostly exposed Watzmann east face and exposed Ice Chapel, which is typically found earlier in the summer season (e.g. 19 July, Fig. 2). We used this methodology since no direct measurements are available at the Watzmann east face and no meteorological measurements are available at the Ice Chapel for 19 July. Furthermore, heating of the sensors by shortwave radiation might also affect air temperature measurements. Initial atmospheric stability is thus only an approximation of local atmospheric conditions. Since simulations are not run for $24 \mathrm{~h}$ integration time the integration time does not allow for the full adaptation of the near-surface air field to the daily cycle of radiation. As discussed above, however, we expect the flow field to adapt to thermal forcing during the integration time, also changing the local atmospheric stability, in particular over the ice field surface.

We used the same initial wind velocities, air temperatures, and surface temperatures for both set-ups as no meteorological measurements are available at the Ice Chapel area on 19 July and for comparability of numerical results on flow development driven only by differences in radiation. Initial air temperature and wind velocity were obtained from mobile measurements at the moraine Ice Chapel for 26 October. The initial surface temperature of snow-free areas was set to $11.6^{\circ} \mathrm{C}$, as measured at station Kühroint (Fig. 2). The initial surface temperature of the Ice Chapel surface was set to $0^{\circ} \mathrm{C}$. 


\section{Results and discussion}

\subsection{Long-term surface area change between 1973 and 2017}

Continuous measurements of the ice field surface between 1973 and 2018 have been performed using different remotesensing methods (see Sect. 2.2.2). Measurements of the ice surface in the autumn of 6 individual years (Table 1) show that the minimum surface area at the end of the ablation period decreased from $44100 \mathrm{~m}^{2}$ in 1973 to $12500 \mathrm{~m}^{2}$ in 2014 with a slightly increasing area between 2014 and $2017\left(+677 \mathrm{~m}^{2}\right)$ and a significant increase between 2017 and 2018. The larger extent measured in 2007 is due to the earlier date of measurement (July). At this early time in the ablation season the surface of the Ice Chapel was even smaller than measured in late September 1973, more than 2 months later in the ablation season, emphasizing the tremendous retreat of the ice field during the last 30 years.

While the planimetric area of the ice field was aligned in the $\mathrm{E}-\mathrm{W}$ direction in 1973 (main axis of slope direction), with a length of almost $500 \mathrm{~m}$, the extent in the N-S direction was less than $400 \mathrm{~m}$. Within the last 30 years the length in the E-W direction was strongly reduced to approximately $200 \mathrm{~m}$. The strongest reduction of the surface area is shown at the upper and lower boundaries (lower and higher elevations) where the thickness of the ice field was smallest (Fig. 4). The reduction of the surface area in the $\mathrm{N}-\mathrm{S}$ directions was much smaller, still featuring a length of around $230 \mathrm{~m}$. This is most probably due to the larger thickness of the ice body there. The profiles shown in Fig. 4 indicate a rather small change in surface height between 1973 and 1994, indicating a small total mass loss of the Ice Chapel but a rapid decrease between 1994 and 2014 with more than $30 \mathrm{~m}$ change in surface height at the main body. Although the surface area increased between 2014 and 2017, measurements evidence a decrease in surface height (few metres) and a total volume loss of $56500 \mathrm{~m}^{3}$ during these three mass balance years. This shows that the change in surface area between 1994 and 2017 was connected to a massive volume loss during the last 2 decades.

\subsection{Measurements of snow accumulation, ablation, and total change in the ice field surface in 2017/2018}

\subsubsection{Snow accumulation October 2017-March 2018}

The map of snow accumulation in winter 2017/2018 was obtained from terrestrial laser scanning before winter on 16 October 2017 and at the end of the winter on 17 March 2018 (Fig. 6). Maximum seasonal snow depth at the station Kühroint was measured on 8 March 2018. At the end of the accumulation season, TLS measurements evidenced between 25 and $40 \mathrm{~m}$ of snow accumulation at the main body of the Ice Chapel. The largest snow accumulation was measured at the upper boundary of the ice body close to the rock wall, with locally more than $40 \mathrm{~m}$ of snow deposition. The lowerelevation area of the Ice Chapel gained between 20 and $39 \mathrm{~m}$ of snow, with decreasing snow accumulation towards the lateral boundary of the Ice Chapel. The mean snow accumulation rate measured at the main body of the Ice Chapel is $32.4 \mathrm{~m}$ (Fig. 6, grey rectangle; Table 3), which is $3000 \%$ of the snow depth measured at the flat field site Kühroint (Fig. 1), showing a snow depth of $1.07 \mathrm{~m}$ at this day and a maximum snow depth of $1.39 \mathrm{~m}$ at time of peak accumulation ( $9 \mathrm{~d}$ earlier) (Fig. 5). The large snow depositions at the Ice Chapel could be clearly identified as avalanche deposits (Fig. 1d).

Clearly above-average snow deposition due to avalanching was observed up to a distance of $200 \mathrm{~m}$ downstream of the maximum extent of the Ice Chapel in autumn 2017. The small Ice Chapel showed similar snow accumulation rate with approximately 20 to $35 \mathrm{~m}$ of snow deposition. With less than $0.5 \mathrm{~m}$ of snow accumulation, most areas of the lower part of the rock face above the Ice Chapel show much smaller amounts of snow deposition. Significant snow deposition can be found at the rock face in gullies and avalanche pathways with snow heights between 5 and $10 \mathrm{~m}$, which can be mainly attributed to snow avalanches and snow slides. Areas that are not prone to avalanches, such as the moraine shoulders and slopes in the surroundings of the Ice Chapel, can be clearly distinguished in the snow depth maps from areas where snow deposition is clearly dominated by avalanches. The comparison between mean values in areas not affected by avalanches and areas clearly affected by avalanche deposition shows that approximately $92 \%$ of snow accumulation at the main body of the Ice Chapel can be attributed to avalanching from the large avalanche catchment of the Watzmann east face. Only $8 \%$ of the winter snow accumulation at the Ice Chapel can be ascribed to solid precipitation. However, part of snow deposition in the surrounding area of the ice field could also be influenced by depositions from powder snow avalanches. The estimated values are similar to values published in an earlier study of Rödder et al. (2010), who found a $90 \%$ contribution of avalanches to snow deposition at the Ice Chapel for winter 2006/2007.

Areas where snow accumulation is solely attributed to solid precipitation show snow depths between 1 and $4 \mathrm{~m}$ with a mean snow depth of $2.5 \mathrm{~m}$ (Fig. 6, red rectangle), which is $250 \%$ of the snow depth measured at the flat field site Kühroint (Fig. 1). Due to its funnel-shaped configuration, the Watzmann east face is sheltered from strong winds for most prevailing wind directions (Warscher et al., 2013). The associated reduction of wind speed downstream of the ridge crests and the associated stream-wise flow convergence over the large leeward slopes are assumed to promote higher precipitation rates over the entire wind-sheltered cirque due to preferential deposition of precipitation (Mott et al., 2014). Finally, the high avalanche activity in the area leads to a strong amplification of snow deposition at the Ice Chapel, especially in winter with high snowfall rates. It can thus be assumed that 


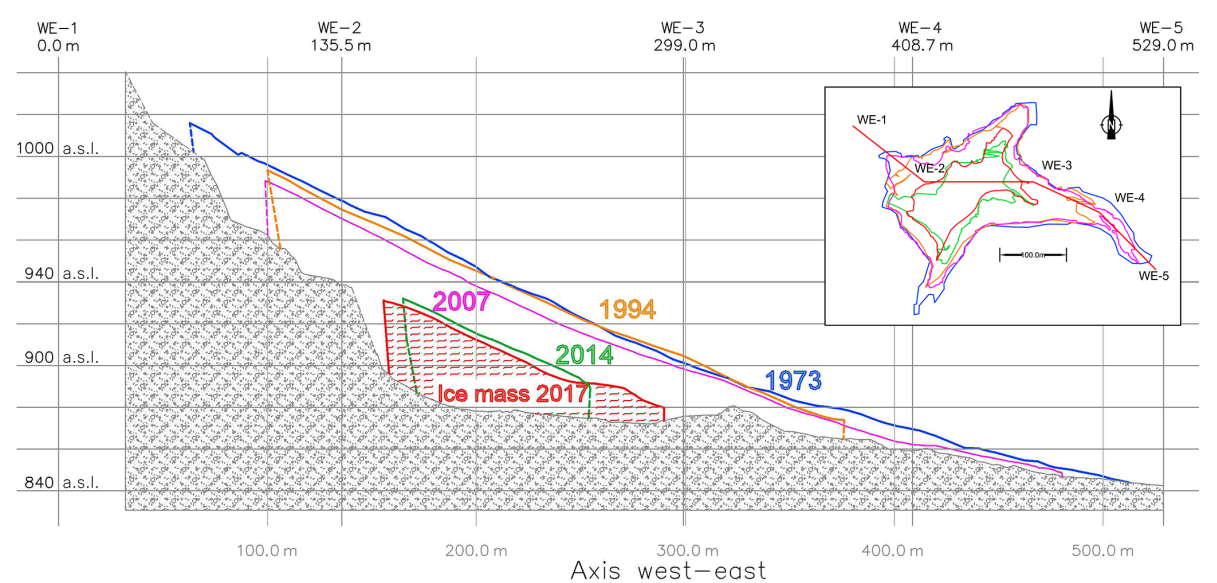

Figure 4. Surface profile of the Ice Chapel measured at the end of the ablation season of the respective years 1973, 1994, 2007, 2014, and 2017.

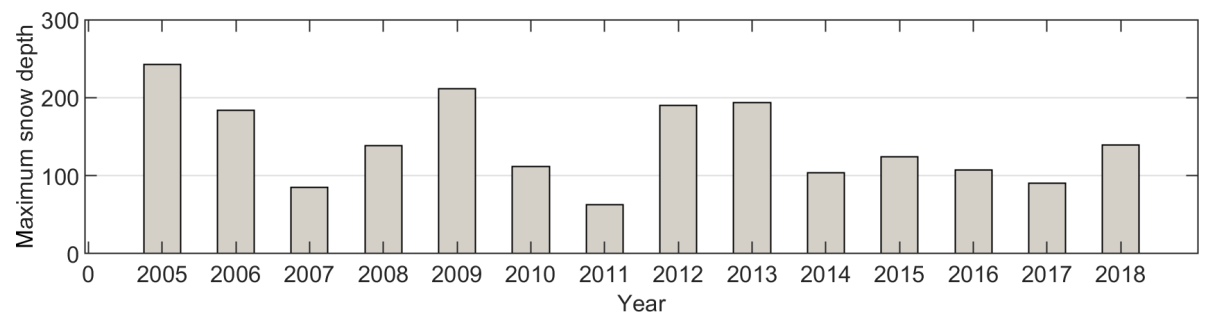

Figure 5. Maximum seasonal snow depths measured at station Kühroint since 2005.

Table 3. Mean and range of snow accumulation, ablation and net surface change October 2017-September 2018.

\begin{tabular}{lrr}
\hline & Range & Mean \\
\hline Snow accumulation & $25-40 \mathrm{~m}$ & $32.4 \mathrm{~m}$ \\
Snow ablation & $15-19 \mathrm{~m}$ & $-17.5 \mathrm{~m}$ \\
Net surface change & $(+) 6-20 \mathrm{~m}$ & $+15.7 \mathrm{~m}$ \\
October 2017-September 2018 & & \\
\hline
\end{tabular}

the relative contribution of avalanching to total winter snow deposition at the Ice Chapel increases with increasing winter precipitation. Due to wind-sheltering and associated low wind velocities in the entire investigation area (Warscher et al., 2013), we assume that snow drift is of minor importance for the winter mass balance of the Ice Chapel.

\subsubsection{Snow ablation March-September 2018 and total surface change during the mass balance year $2017 / 2018$}

Maps of snow ablation during summer 2018 are obtained from terrestrial laser scanning at the start (17 March 2018) and the end of the ablation season (29 September 2018) (Fig. 7a). The difference between the measured surface in October 2017 and September 2018 provided the total surface change during the mass balance year 2017/2018 (Fig. 7b; Table 3).

Measurements evidenced a positive mass balance of the Ice Chapel at the end of the ablation season (September 2018) with a total increase in surface height ranging from $6 \mathrm{~m}$ (at the ice field snout) to $20 \mathrm{~m}$ (central part of the ice field) and a mean change in surface change of $+15.7 \mathrm{~m}$ (Table 3). The thickness of the ice body increased by approximately $100 \%$ at the lowest elevations and by approximately $50 \%-70 \%$ at the central part (Figs. 6b, 4). The length of the ice field also increased by approximately $70 \mathrm{~m}$, which is visible by the downward shift of the ice field snout (Fig. 7).

Since the entire ice field surface was still covered by seasonal snow in late September, the change in surface height at the end of the ablation season is mainly limited to snow ablation. No ice ablation could be evidenced. Snow ablation rates ranged between 15 and $19 \mathrm{~m}$ with the highest ablation at the lower-elevation and the high-elevation parts of the Ice Chapel and a mean snow ablation of $17.5 \mathrm{~m}$ (Table 3 ). A distinct area of lower ablation in summer was measured at the central part of the ice field, where the maximum increase in net surface height was observed. The lowest net surface increase was found at the lower-elevation areas of the Ice Chapel because of the strong snow ablation combined with less avalanche deposition in winter (Fig. 7b). 


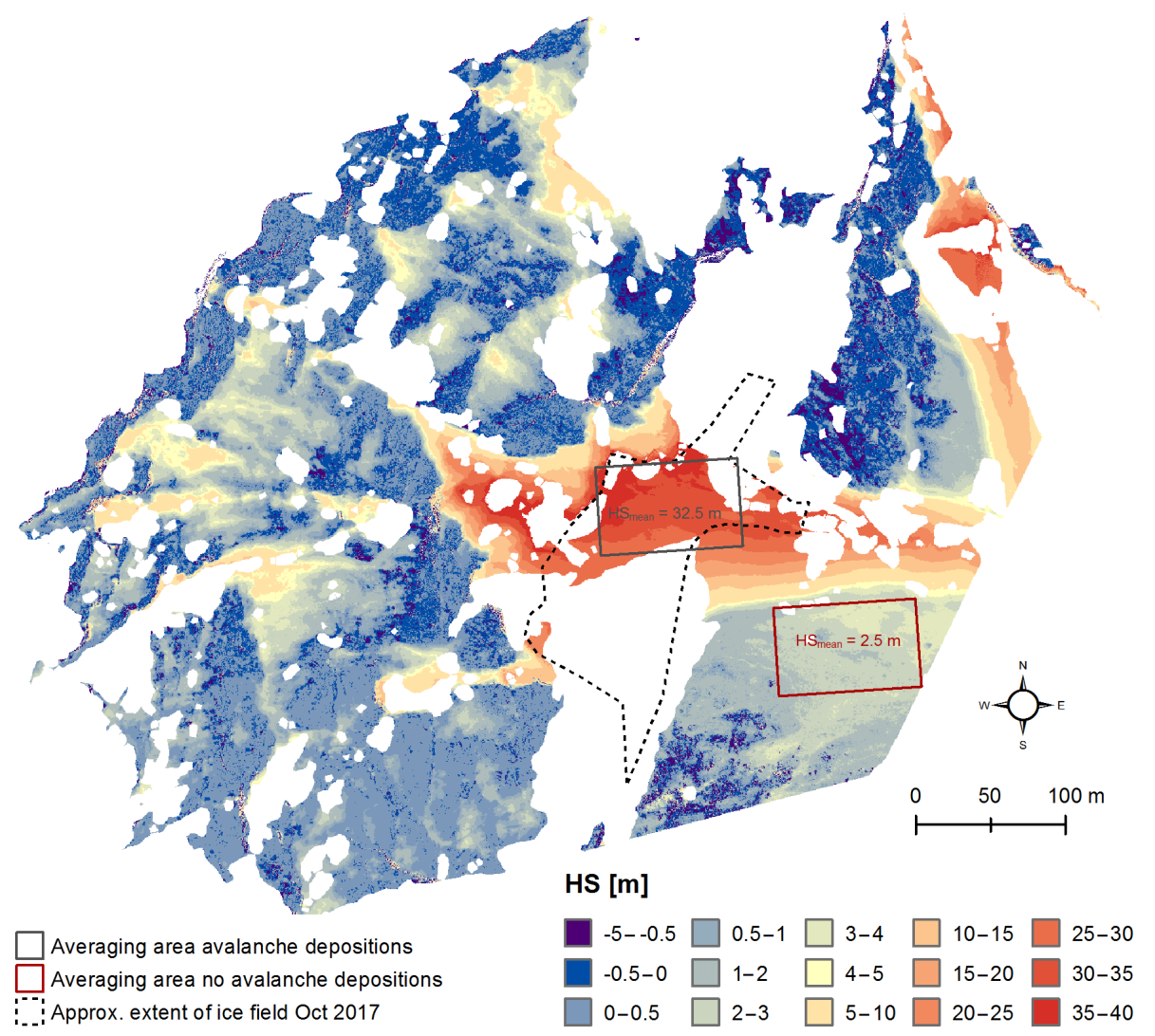

Figure 6. Measured snow accumulation at the Ice Chapel between 26 October 2017 and 17 March 2018, obtained from terrestrial laser scanning (Riegl, VZ6000). Red areas indicate high values of snow accumulation and blue areas indicate low values. White areas represent measurement shadows. The dashed black line indicates the roughly estimated area of the Ice Chapel in October 2017. The boxes highlight averaging areas for the estimation of mean snow accumulation in areas affected by avalanching (grey box) and not affected by avalanching (red box).

Contrary to mass balance measurements of large glaciers in the Alps, revealing negative mass balances since 1970 (Kaser et al., 2006), the survey of the perennial ice field did not reveal a continuing decrease from year to year, but showed some years with an increasing net surface area (Fig. 3), such as in 2017 and 2018 and even a clearly positive mass balance in 2018 (Fig. 7). These measurements highlight the ability of the Ice Chapel to feature significant mass gain during individual years with strong precipitation in winter driving avalanche deposition at the Ice Chapel. Such an increase in surface height by more than $50 \%$ in one mass balance year is only possible for topographic locations featuring anomalous snow accumulation. The positive mass balance is connected to above-average precipitation in winter (Fig. 5) and related avalanche deposition at the Ice Chapel and to a long snow cover duration, as presented by Rödder et al. (2010). While winter snow accumulation was small between 2013/2014 and 2016/2017 (Fig. 5), winter snow accumulation was above average in winter 2017/2018, explaining the positive mass balance for this year. A late melt out of the snow cover in the ablation season favours a positive mass bal- ance of the ice field by lowering the surface albedo and thus lowering net shortwave radiation entering the Ice Chapel.

\subsection{Measured and modelled micrometeorology at the Ice Chapel: katabatic flow and associated effects on near-surface air temperatures and turbulent heat exchange}

\subsubsection{Measured air temperature field}

Maps of air temperatures $\left(T_{\mathrm{A}}\right)$, measured at $2 \mathrm{~m}$ above ground, are presented in Fig. 8 for 26 October 2017, 12:00 13:00. At this time, the entire area of the Ice Chapel and its surroundings was shaded from sun and no clouds were present. Under uniform solar radiation, measurements evidence a very high spatial variability of $T_{\mathrm{A}}$ at the Ice Chapel and downstream of the ice field. Measurements showed values of about $8.5^{\circ} \mathrm{C}$ at the lowest part of the Ice Chapel and a $T_{\mathrm{A}}$ minimum of $6.9^{\circ} \mathrm{C}$ measured a few metres downstream of the ice field snout where cold air flow exits the ice field body. Downstream of the ice field, air temperatures were lowest at the bottom of the moraine slopes and continuously 


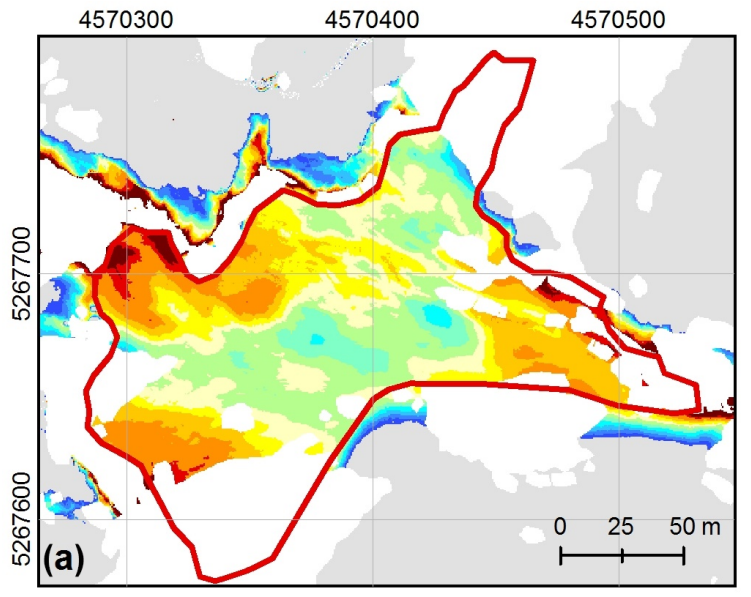

Surface change summer $[\mathrm{m}]$
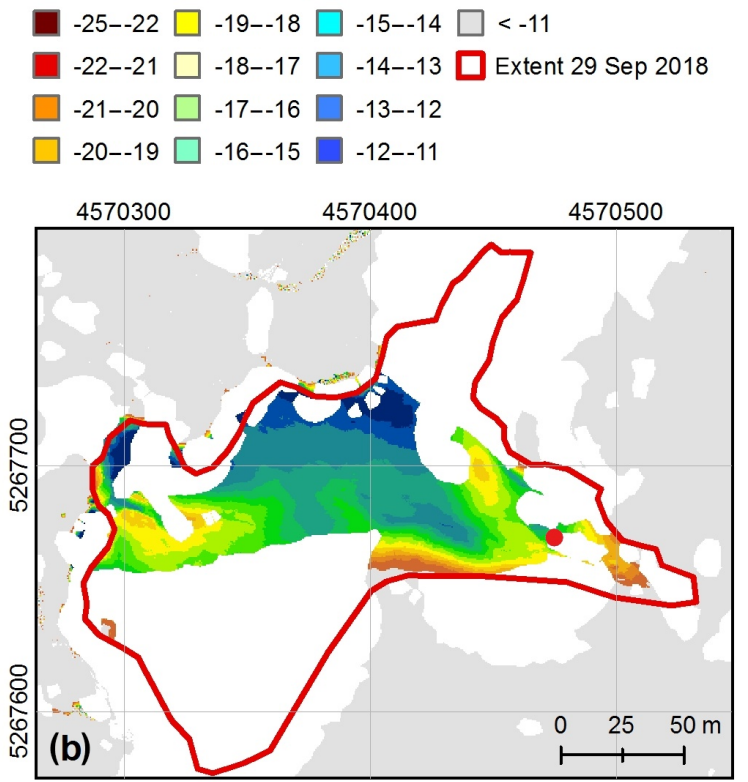

Surface change Oct 2017-Sep 2018 [m]

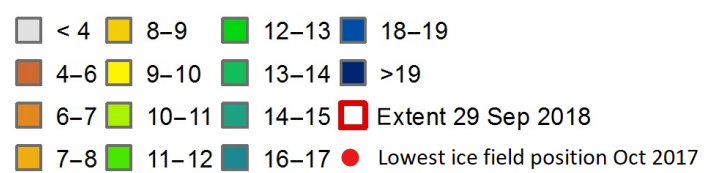

Figure 7. (a) Surface change during the ablation season 2018 (March-September) (b) and the surface change for the mass balance year 2017/2018 (October 2017-September 2018). The red dot marks the position of the ice field snout in October 2017.

increased along the slopes with a maximum $T_{\mathrm{A}}$ of $12.7^{\circ} \mathrm{C}$ at the top of the moraine, resulting in an air temperature gradient of $1.5^{\circ} \mathrm{C}$ at $10 \mathrm{~m}$ distance. Measurements of relative humidity (not shown) also reveal much higher relative humidity with values ranging between $80 \%$ and $90 \%$ close to the ice field snout and $76 \%$ above the ice field surface. Relative humidity was much lower at the top of the moraine with values of about $60 \%$ indicating much drier air there. Measurements thus suggest the presence of two different cold air flows at

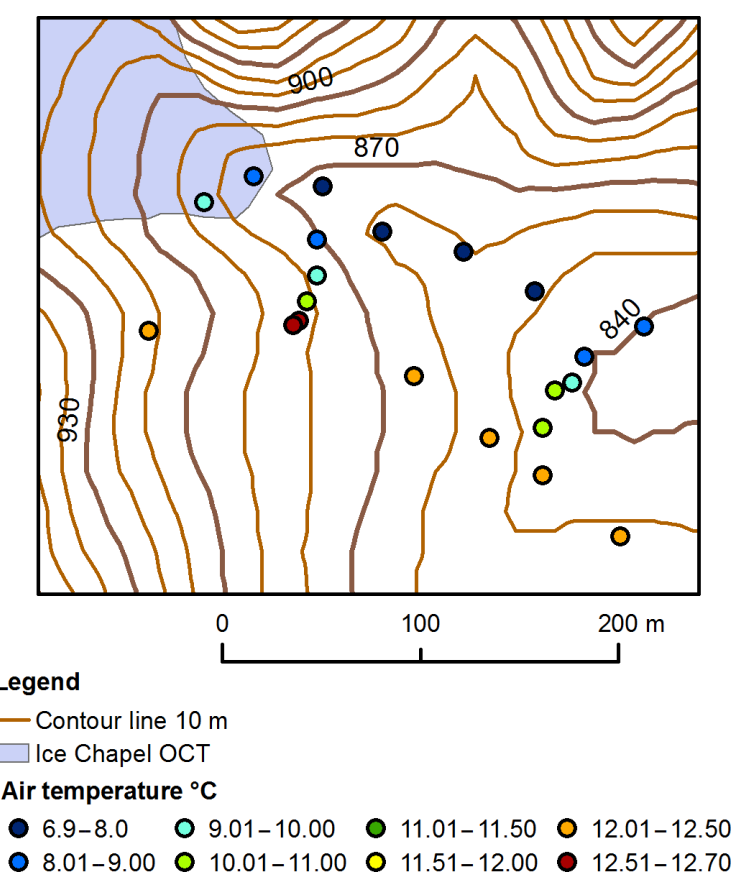

Figure 8. Air temperatures $T_{\mathrm{A}}$ measured on 26 October 2017 with mobile meteorological stations at $2 \mathrm{~m}$ above the surface.

the Ice Chapel with different origins. A cold and humid air flow originate from the caving system of the Ice Chapel and a katabatic flow evolves at the Ice Chapel surface, both draining down the gully downstream of the ice field. Conversely, the upper part of the moraine appeared to be not affected by a katabatic flow system at this time of the day.

\subsubsection{Measured surface temperature fields}

Surface temperature measurements have been conducted using an IR camera during $4 \mathrm{~d}$ in July 2018 in order to obtain an indirect measure of small-scale micrometeorology in the area of the Ice Chapel. Resulting surface temperature $\left(T_{\mathrm{S}}\right)$ maps are presented in Fig. 9 for 19 July 2018. Absolute values of $T_{\mathrm{S}}$ might include uncertainties due to corrections not applied to the data. We thus only discuss the relative values of surface temperatures in space and time as earlier studies showed a high accuracy of relative values of IR measurements (Grudzielaneck and Cermak, 2015; Mott et al., 2017). As the Ice Chapel surface was at its melting point throughout the measurement days, the analysis of changes in surface temperatures was limited to the ice-free surrounding area, mainly featuring debris and rock. Transect lines (L1, L2) are shown for different points in time during $2 \mathrm{~d}$ (12 and 19 July) revealing the spatial and temporal dynamics of $T_{\mathrm{S}}$ along the moraine slopes (Fig. 10a-d). Note that the camera position slightly moved over the day on 12 July 2018 due to instabilities of the tripod. The standard deviation of $T_{\mathrm{S}}$ during the day, reflecting the cooling and warming rates of surface pixels over the day, is calculated from measurements conducted 

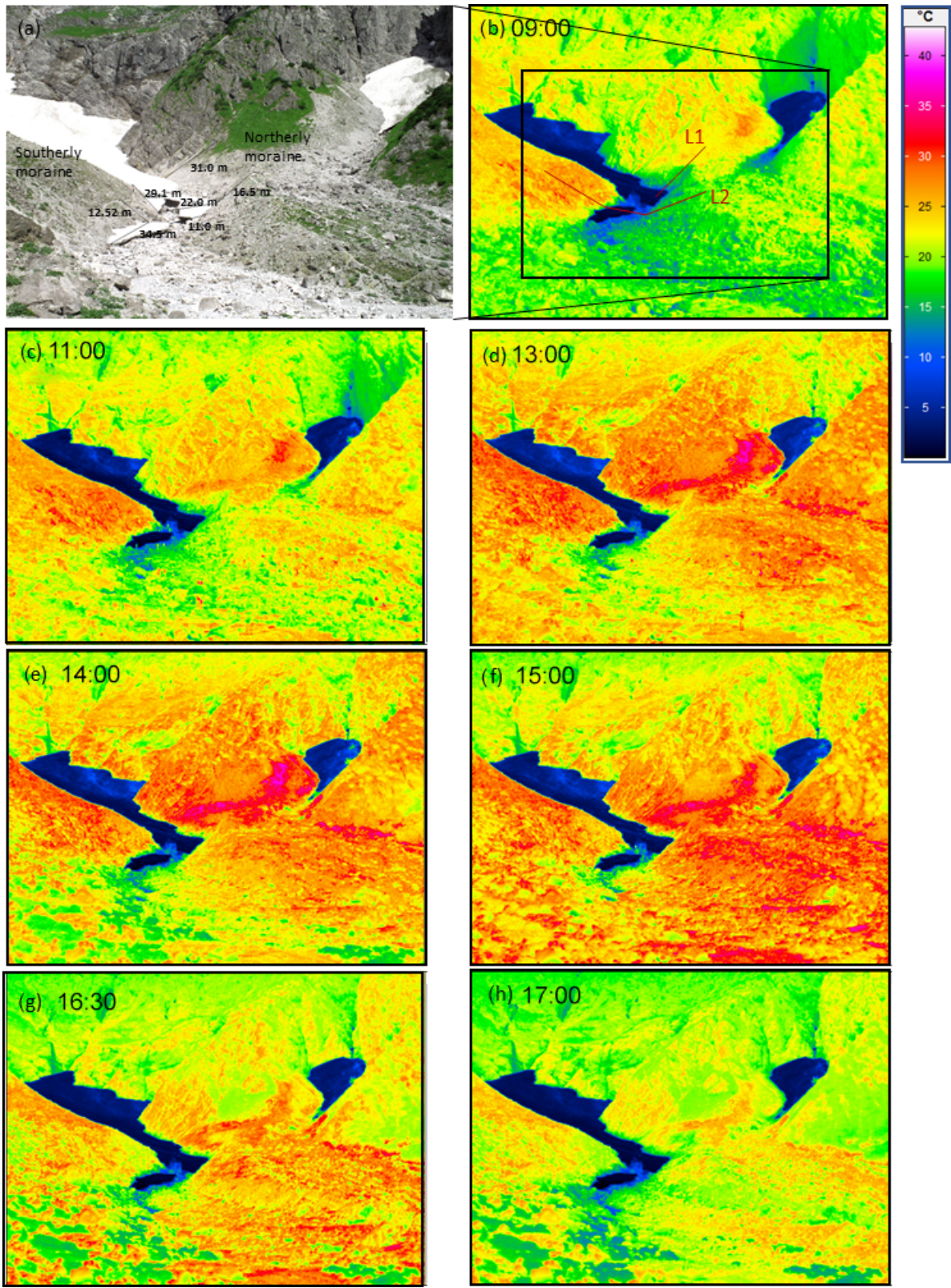

Figure 9. Surface temperature maps obtained from IR camera on 19 July 2018 at 09:00, 11:00, 13:00, 14:00, 13:00, and 17:00. Dark blue areas represent the ice/snow surface of the Ice Chapel and the small Ice Chapel. Values given in (a) indicate measured distances in metres. Transects marked with L1 and L2 in (b) show locations of transects presented in Fig. 10.

at six different measurement times (Fig. 9a-d) and is given in Fig. 10e, f for 19 July. This was the only day without shifts of the images during the day and without influences of local cloud formations on local $T_{\mathrm{S}}$. Potential incoming radiation for the respective area is shown for 19 July in Figs. $2 b$ and 11. Contrary to the measurement day in October, most of the area was exposed to the sun from 10:00 until 14:00 with small spatial variations in the potential incoming solar radiation at the Ice Chapel and its surroundings (Fig. 11). In the morning hours parts of the rock face were shaded, receiving no direct shortwave radiation. After 14:00, the south-westerly moraine received less radiation than the easterly one. However, radiation is spatially consistent along the individual moraine slopes throughout the measurement days. We thus expect that small-scale spatial differences in surface temperatures along the moraine slopes can be mainly attributed to differences in the turbulent heat exchange between the surface and the atmosphere, mainly driven by small-scale dynamics of the atmospheric boundary layer flow. 


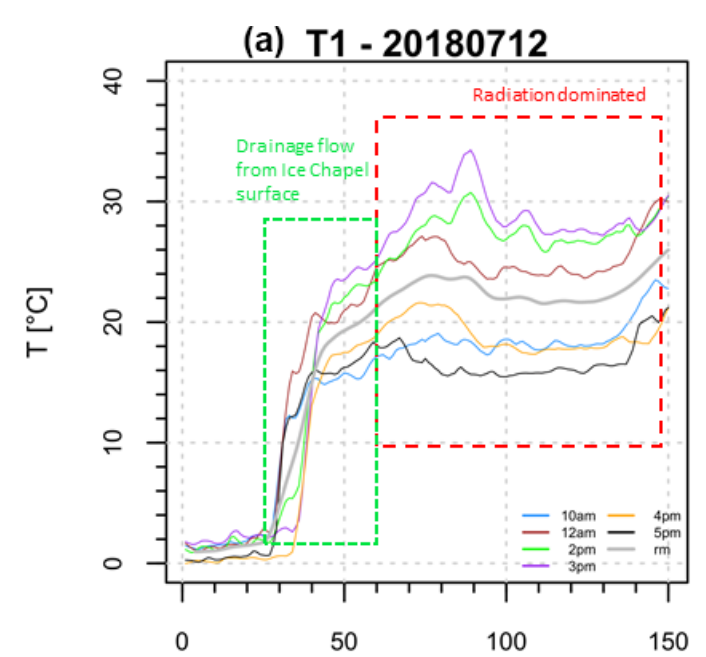

(c) $\mathrm{T} 1-20180719$

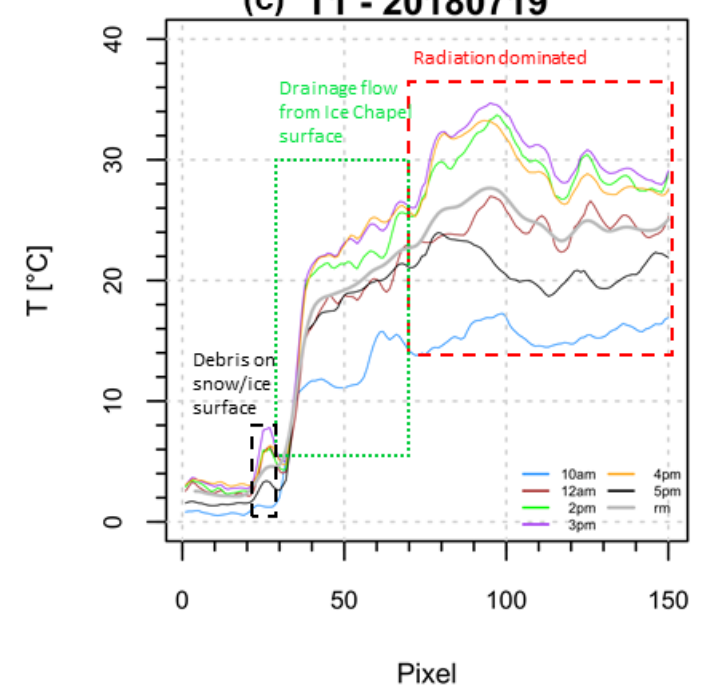

(e) T1 - 20180719

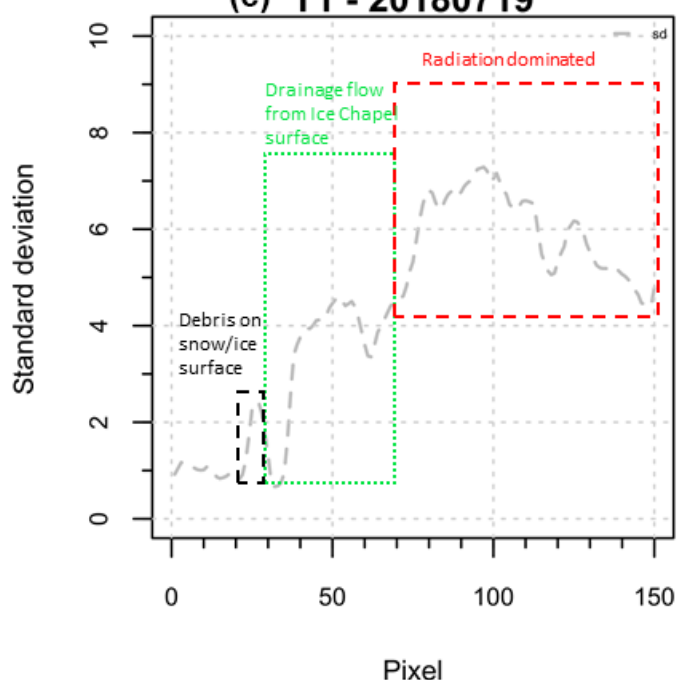

(b) T2 - 20180712

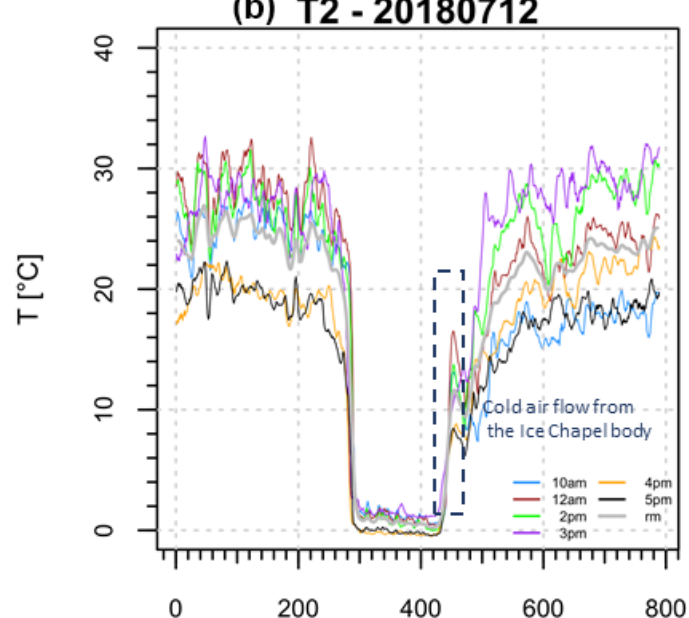

(d) T2 - 20180719

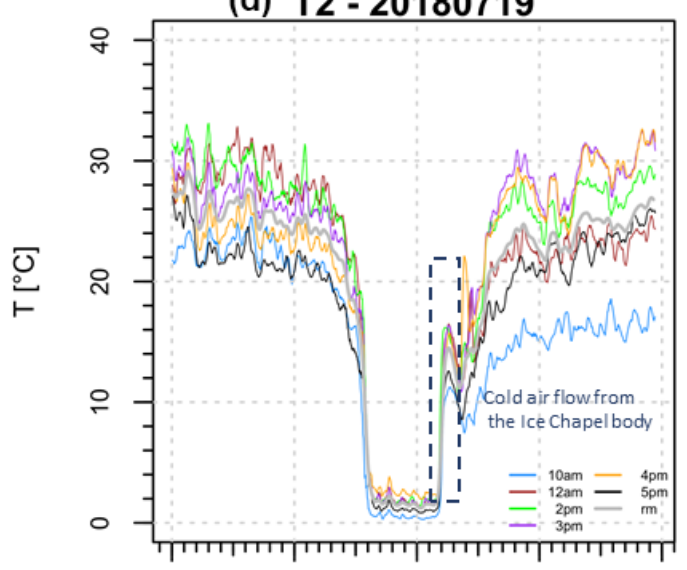

$\begin{array}{llll}0 & 200 \quad 400 \quad 800\end{array}$

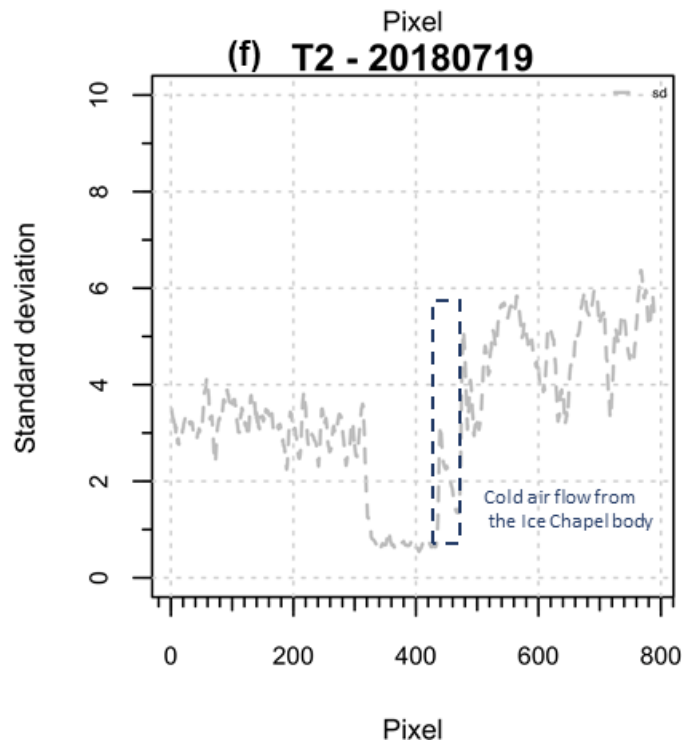

Figure 10. Transect lines showing surface temperatures along the moraine slopes measured on 19 July 2018 at 10:00, 12:00, 14:00, 16:00, and 17:00 for two measurement days and at two different locations (a-d), shown in Fig. 7b. Standard deviation of $T_{\mathrm{S}}$ measured at different points in time is presented in (e) and (f) respectively. 

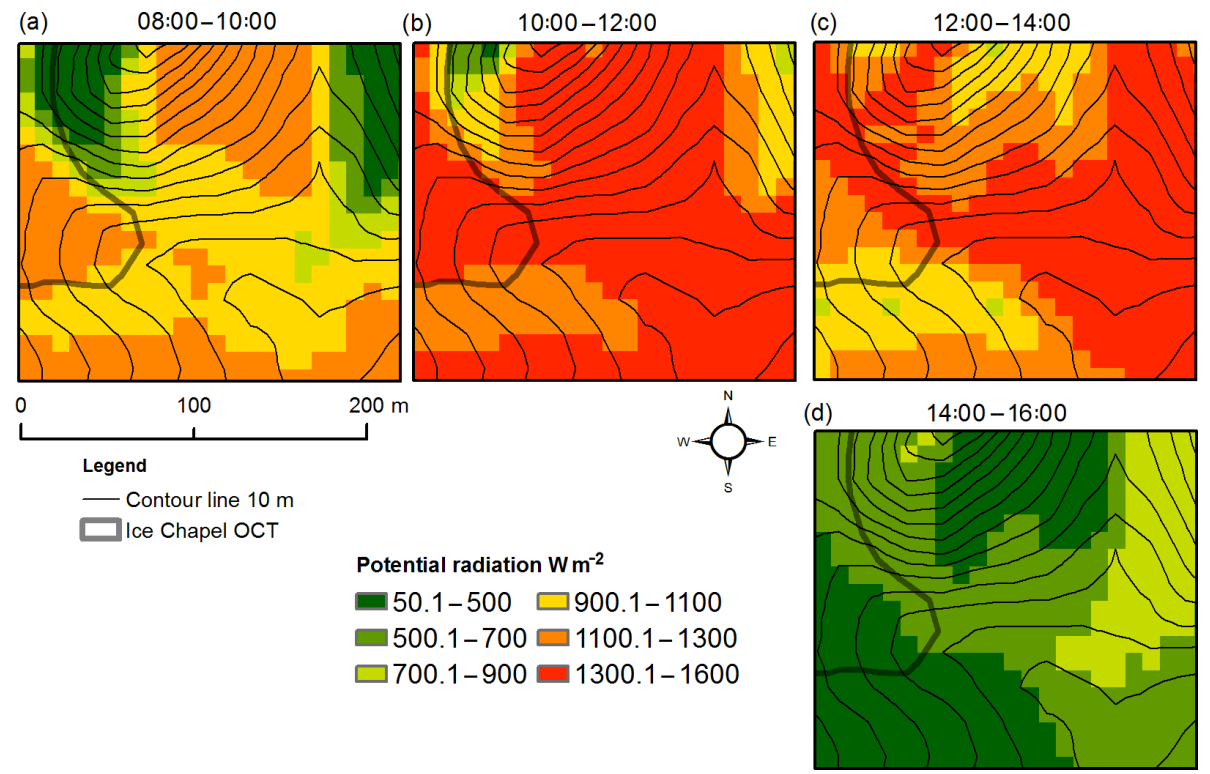

Figure 11. Potential shortwave radiation for 19 July 2018 at (a) 08:00-10:00, (b) 10:00-12:00, (c) 12:00-14:00, and (d) 14:00-16:00.

Maps presented in Fig. 9 highlight the high spatial variability of $T_{\mathrm{S}}$ during the course of the day in the surrounding area of the main body of the Ice Chapel. Air temperatures measured at Kühroint $(1420 \mathrm{~m})$ ranged between 17 and $18^{\circ} \mathrm{C}$. Maxima of $T_{\mathrm{S}}$ are revealed at the flat areas at the top of the moraines. $T_{\mathrm{S}}$ is declining with decreasing distance to the ice surface (e.g. area at L1). Downstream of the Ice Chapel (area at L2, Fig. 9) $T_{\mathrm{S}}$ maps obtained in July show very similar spatial patterns as observed and modelled for the $2 \mathrm{~m} T_{\mathrm{A}}$ in October (Fig. 10). These patterns are characterized by strong temperature gradients of several degrees along the moraine slopes (Fig. 9). Surface temperatures persist at significantly lower values in the entire downstream area at the bottom area of the gully. Transect lines L1 shown for certain points in time (Fig. 10a, c) indicate a very strong suppression of $T_{\mathrm{S}}$ in the lowest few metres of the moraine slopes above the Ice Chapel. In this area, measurements evidence a strong temperature gradient of up to $2.5^{\circ} \mathrm{C}$ change in surface temperature per pixel (approx. $0.2-0.3 \mathrm{~m}$ resolution) with strongly increasing surface temperatures with increasing distance to the ice surface. A local increase in surface temperatures of several degrees at the surface of the IceChapel marks an area of debris cover at the snow surface (Fig. 10c). As discussed above, radiation effects cannot explain the strong spatial differences in daytime surface temperatures along the slopes. We thus assume that a thermal flow draining down the ice field and downstream gullies is cooling the surface at the lower parts of the moraine slopes during the day. As discussed above, we could also observe such a drainage flow during high-resolution air temperature measurements in October (Fig. 10). The existence of the ice field throughout the year and partial shading of the very steep rock face suggest the presence of the katabatic flow system over the entire ablation season.

Transect line L2 (Fig. 10b, d) reveals the influence of two flow regimes already discussed for the air temperature fields. At the gully downstream of the snout of the Ice Chapel, surface temperatures are affected by the cold air outflow from the Ice Chapel caving system. Surface temperatures are up to $10^{\circ} \mathrm{C}$ colder than measured a few metres above. With increasing height above the gully surface, surface temperatures show large spatial gradients due to the influence of the drainage flow originating from the Ice Chapel surface with significantly warmer air temperatures than the cold air outflow below. The drainage flow at the ice field surface appeared to be well-developed in the morning (10:00, Figs. 10b and 11), originating from the shaded parts of the rock face draining down the shaded areas of the large and small Ice Chapel (Figs. 9b, 11a) and merging at the north-easterly moraine. The well-developed katabatic wind appeared to persistently cool the surface in the morning hours by advecting colder air from the rock face, which is also visible in Fig. 10b, $\mathrm{d}$ with much colder morning surface temperatures at the north-easterly moraine than on the south-westerly moraine. At noon, surface temperatures are balanced between both moraine shoulders, most probably due to an attenuation of the drainage system, limiting the drainage flow to the lowest few metres above the gully surface. These strong differences in surface temperatures are clearly visible for both days presented in Figs. 9 and 10.

Standard deviations of $T_{\mathrm{S}}$ are strongest at the upper parts of the moraine slopes, reflecting a significantly stronger increase in surface temperatures until late afternoon than at the lowest few metres above the Ice Chapel. Surface tempera- 
tures increase between 10:00 and 15:00 by about $10-17^{\circ} \mathrm{C}$ at the upper sections of the moraine slopes, peaking at the moraine shoulders. At the lower parts of the moraine slopes, surface temperatures increased by only 3 to $6^{\circ} \mathrm{C}$, indicating a suppression of daytime surface heating in areas affected by the drainage flow (Fig. 10), resulting in a significantly lower standard deviation of $T_{\mathrm{S}}$ (Fig. 10e, f). Standard deviation of $T_{\mathrm{S}}$ is especially small at the debris-covered location at the Ice Chapel surface (Fig. 10c, e), indicating a strong cooling effect of the drainage flow close to the ice surface. Not only surface heating is suppressed by the presence of the drainage flow, but also the cooling of the surface after sunset. As soon as the area becomes shaded, surface temperatures drop by $9{ }^{\circ} \mathrm{C}$ (L1) and $7-9^{\circ} \mathrm{C}$ (L2) at areas assumed to be not affected by drainage flows but only by $3-6^{\circ} \mathrm{C}(\mathrm{L} 1, \mathrm{~L} 2)$ at the lower parts of the slopes. We explain the extenuated surface cooling by higher turbulent heat exchange in these areas forced by higher near-surface wind velocities. Similar effects of the katabatic flow are expected to take place at the ice field surface, attenuating the warming of near-surface air temperatures during the day but also attenuating the cooling of ice surface during night.

\subsubsection{Modelled air temperature and wind field}

Simulation results obtained from the atmospheric model ARPS using two different model set-ups (see Sect. 2.4) show near-surface air temperature fields characterized by large horizontal temperature gradients over the ice field area with the coolest air temperatures at the lowest downwind part of the ice field and at the bottom of the moraine slopes (Fig. 12a, c). Spatial patterns of air temperatures are similar to measured patterns of air temperature (Fig. 12) and surface temperature (Figs. 9, 10) but show smaller spatial air temperature gradients. The development of the air temperature field differs between the two model set-ups, mainly driven by differences in flow field development. For both model set-ups, a katabatic flow is present over the Ice Chapel but with differences in the development such as the onset, the depth, and the magnitude of wind velocity maxima of the drainage flow (Fig. 13).

Model results show that in case of a shaded rock face (Fig. 12a, b, set-up 1), the cold air drains down the very steep slopes, resulting in a well-developed katabatic flow draining down the Ice Chapel with a wind speed maximum ranging between 7 and $9 \mathrm{~m}$ above the ice surface (Fig. 13). Air temperature fields during such a situation were measured at 12:00 on 26 October (Figs. 8, 12). Signatures on the surface temperatures of such deep and well-developed katabatic flows have been observed by IR images during the morning and late afternoon when the lower parts of the rock face are shaded from sun. In case of well-developed katabatic flows, the flow speeds up over the cold surface of the ice field, further decreasing near-surface air temperatures over the lower part of the Ice Chapel and downwind of the perennial ice field. In the area of the ice field, air temperatures range from 7.8 to $12.4^{\circ} \mathrm{C}$. The cold air flow exiting the Ice Chapel caving system at the snout, which was observed by measurements, is not captured by the model. This is one reason why the modelled temperature range downstream of the Ice Chapel is smaller than the measured one, with minimum values higher than evidenced by measurements. Also, the horizontal distance between minimum and maximum air temperature increases from $40 \mathrm{~m}$, evidenced by measurements to $160 \mathrm{~m}$ in the model, most probably caused by the overestimation of the depth of the katabatic flow by the model due to resolution restrictions. The representation of the katabatic flow depth is known to be strongly dependent on the near-surface vertical grid resolution (Mott et al., 2015). A vertical resolution of approximately $2 \mathrm{~m}$ close to the surface appears to be too coarse to capture shallow katabatic flows, which typically have a jet maximum of less than $2 \mathrm{~m}$ above ground (Denby, 1999; Oerlemans and Grisogono, 2002).

Model results of set-up 2 (Fig. 12c, d) suggest that in the absence of katabatic flow development at the rock face, the cooling of the near-surface air by the ice surface results in the onset of a very shallow katabatic flow directly over the perennial ice field with an increase in wind velocity with increasing fetch distance over snow/ice (Fig. 13). Similar to set-up 1, maximum wind velocities are found downwind of the Ice Chapel, coinciding with minimum air temperatures. At the central part of the Ice Chapel, near-surface wind velocities are, however, significantly smaller compared to the well-developed katabatic flow revealed by set-up 1 . Due to the much shorter fetch distance of the katabatic flow, the depth of the katabatic flow (Fig. 13) and also the horizontal stretching of the flow is much smaller than for set-up 1. Similar to measurements, air temperatures reach a minimum at the lowest part of the Ice Chapel and at a distance of $150 \mathrm{~m}$ downstream of the ice field snout.

\subsubsection{Indications of flow field development on the heat exchange and snow ablation patterns}

The onset and development of the katabatic flow appears to have a significant influence on the turbulent heat exchange at the ice surface (Fig. 14). For situations with a well-developed katabatic flow (set-up 1), near-surface wind velocities of more than $4 \mathrm{~m} \mathrm{~s}^{-1}$ and positive near-surface temperature gradients result in a strong turbulent mixing and strong downward sensible heat flux with maximum values along the entire centre line of the ice field. Conversely, in the case of a shallow katabatic flow that developed directly over the ice field (situation 2), wind velocities are much lower at the upper and central parts of the ice field, coinciding with a smaller turbulent sensible heat exchange there. Increasing wind velocities in downwind distance involved increasing downward sensible turbulent heat exchange towards the lower parts of the ice field because of the approximately linear dependence of turbulent heat exchange on the wind velocity (Dadic et 

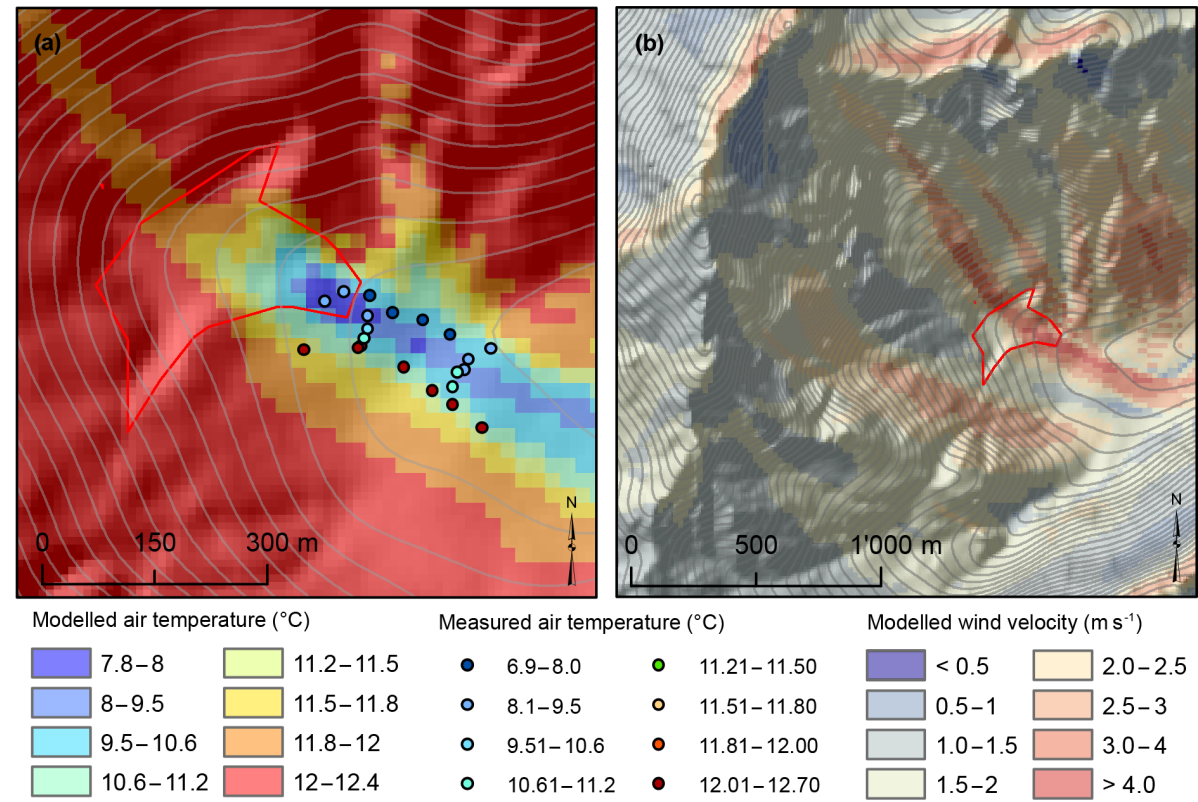

Measured air temperature $\left({ }^{\circ} \mathrm{C}\right)$

- 6.9-8.0

- 11.21-11.50

Modelled wind velocity $\left(\mathrm{m} \mathrm{s}^{-1}\right)$

- 8.1-9.5

- $9.51-10.6$

○ 10.61-11.2

○ $11.51-11.80$

- $11.81-12.00$

- 12.01-12.70

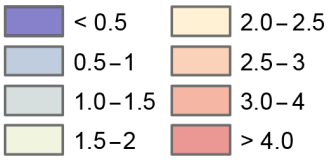

Contour lines $30 \mathrm{~m}$ Ice Chape
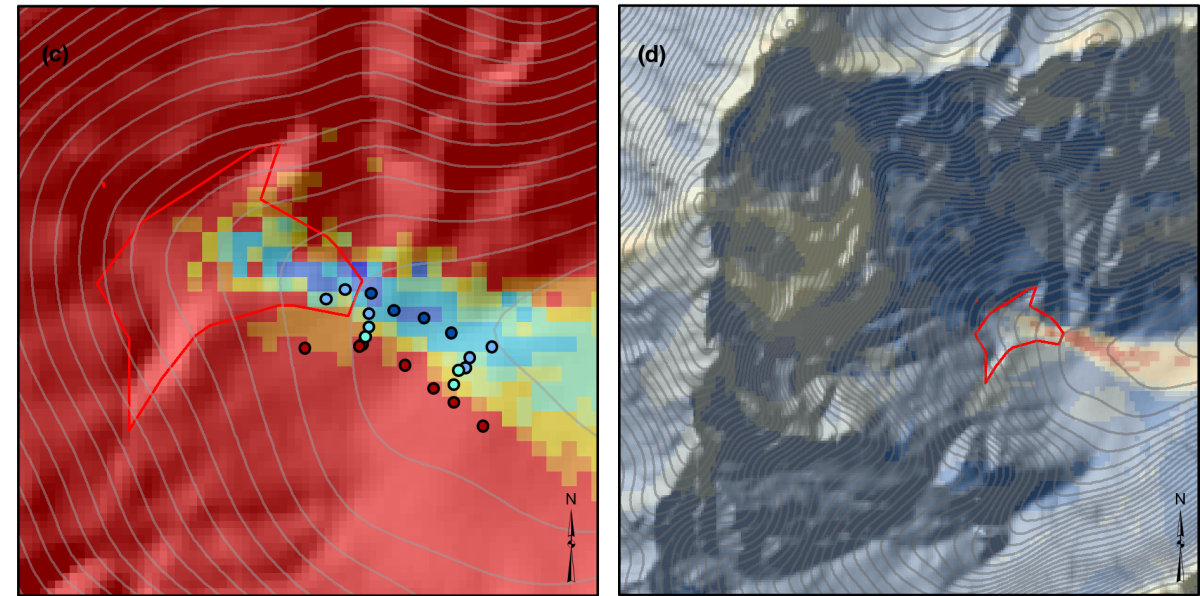

Figure 12. Air temperature and wind velocity fields modelled with the atmospheric model ARPS, initialized by a stable atmosphere (a, b) and by a neutral atmosphere (c, d). Fields are shown for the first model level above ground with an average height of $2 \mathrm{~m}$ above the ice field surface. Simulations were initialized at 12:00 and were run for an integration time of $3600 \mathrm{~s}$.

al., 2013). Although turbulent fluxes are locally higher at the lower parts due to higher mean near-surface air temperatures than for the well-developed katabatic flow situation, the average turbulent sensible heat flux at the ice field surface is calculated to be significantly smaller (Fig. 14). This confirms earlier results presented by Mott et al. (2015) showing stronger turbulent heat fluxes in situations with welldeveloped katabatic flows compared to shallow katabatic flows. The strong katabatic winds enhance mechanical turbulence close to the surface and remove the shallow stable layer close to the ice surface that typically promotes a suppression of turbulent heat exchange. Modelled mean turbulent heat fluxes at the ice field surface (Fig. 14) were smaller in the case of weaker and more shallow drainage flows due to a decoupling of the atmospheric layer adjacent to the ice field surface from the warmer air above. These model results are similar to results discussed in Mott et al. (2015), who emphasized the isolation effect of shallow katabatic winds over large snow fields, also referred to as lateral atmospheric decoupling. Model results suggest that in such situations, the snow and ice melt is only marginally affected by higher ambient air temperatures.

Since the analysis on the temporal and spatial evolution of surface temperatures indicated a dominance of the shallow katabatic flow in summer, we expect the isolation effect of the katabatic flow to strongly affect the mass balance of the 


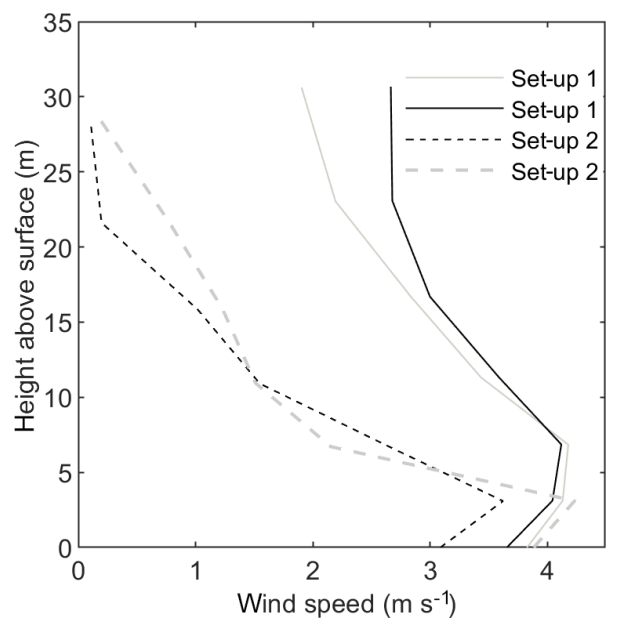

Figure 13. Near-surface profiles of wind speed for set-up 1 (solid line) and set-up 2 (dashed line) above the Ice Chapel surface. Grey lines show profiles at locations further downwind.

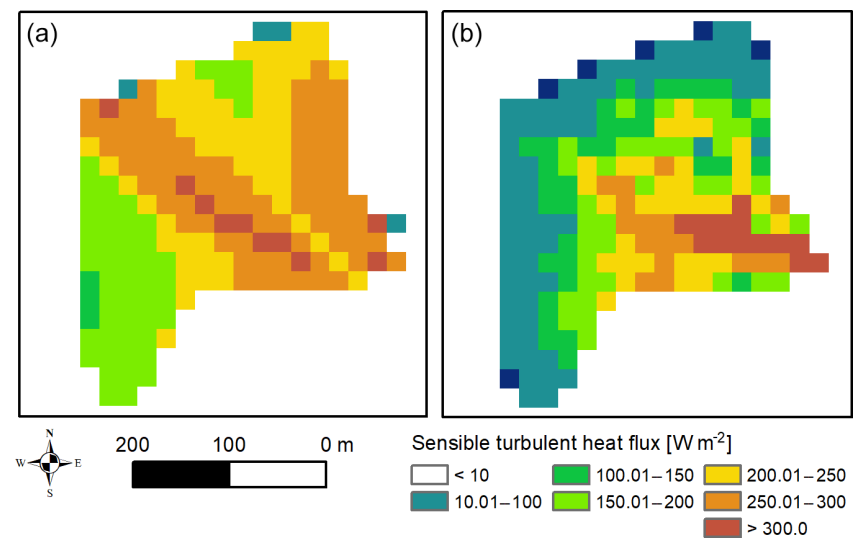

Figure 14. The sensible turbulent heat flux at the ice field surface modelled with the atmospheric model ARPS, initialized by a stable atmosphere involving a well-developed katabatic flow (set-up 1, a) and by a neutral atmosphere involving a shallow katabatic flow onset at the ice field surface (set-up 2, b).

ice field during the ablation season. Snow ablation measurements (Fig. 7a, b) evidenced the smallest ablation rates at the central part of the ice field and a strong increase in ablation rates with downwind distance. The lateral decoupling effect of the shallow katabatic flow might partly explain these ablation patterns with lower sensible heat fluxes at the central part of the ice field and the increasing heat exchange in downwind distance. The effect of lateral decoupling also coincides with the observed attenuating effect of the katabatic flow on the heating and cooling rates of surface temperatures. Maximum snow ablation rates at high-elevation areas, however, cannot be explained by modelled flow field dynamics. One reason for above-average snow ablation in this region might be the larger amount of debris accumulated at the boundary areas adjacent to the rock face and the moraine slopes. Other ef- fects could be strong longwave radiation from the surrounding rock face and stronger subsidence of the surface at the upper boundaries of the ice field where the lateral crevasses are most pronounced.

\section{Conclusions}

This study presents a detailed investigation of the relative contribution of accumulation and ablation processes driving the mass balance of the lowest perennial ice field of the Alps, i.e. the Ice Chapel, located far below the climatic snow line, making it into a popular tourist attraction. The long-term monitoring of the surface change of the ice field during the last 3 decades, applying different remote-sensing techniques, evidenced a dramatic decrease in the ice field area between 1973 and 2014 but a steady mass balance between 2014 and 2017 and a strong increase in surface height between 2017 and 2018. In order to analyse different factors allowing the survival of the perennial ice field until today, we presented a detailed analysis of the winter and summer surface change of the ice field in 2017/2018. High-resolution TLS evidenced an increase in surface height of the ice field by $14.5 \mathrm{~m}$ on average (around 50\%-100\% increase relative to ice body thickness) and an increase in length by around $25 \%$. The experimental and numerical analysis suggested a clear dominance of snow avalanches on the winter mass balance, contributing $92 \%$ to the total snow deposition at the Ice Chapel with a mean snow depth of $32.4 \mathrm{~m}$. Only $8 \%$ of the total winter snow accumulation was gained by snowfall at the ice field. These results clearly suggest that the orographic setting allowed the perennial ice field to survive at such a low elevation by gaining $3000 \%$ of winter snow accumulation compared to a nearby flat field snow station. These findings emphasize the tremendous effect of avalanching on the survival of very small glaciers or perennial ice fields, which are often located far below the climatic snow line. Precipitation via preferential deposition in this wind-sheltered area only indirectly contributed to the mass balance of the ice field by resulting in above-average snow accumulation in the avalanche release area of $1.6 \mathrm{~km}^{2}$ of the $2000 \mathrm{~m}$ high Watzmann east face, amplifying avalanche deposition at the ice field. This study thus suggests that the existence of the perennial ice fields is due to anomalous winter accumulation at those locations, with winter precipitation being multiplied by preferential deposition of snowfall and/or redistribution of snow by avalanches.

Earlier studies on the mass balance of very small glaciers at low elevations also suggested that the respective orographic setting typically promotes micrometeorological processes suppressing ablation in summer (e.g. Denby and Greuell, 2002; Oerlemans and Van Den Broeke, 2002; Petersen et al., 2013). In the presented case study, an analysis of the micrometeorology revealed that the specific topographic setting affects the energy balance at the ice field surface. Topographic shading by the steep rock face involves low so- 
lar radiation and a local minimum of air temperatures at the ice field compared to nearby weather stations, particularly in late summer. The existence of a katabatic flow system over the ice field could be evidenced by measuring air and surface temperature fields. The temporal and spatial dynamics of the signature of the flow system revealed by the surface temperature maps suggests two different cold air flows during daytime: first, a katabatic flow draining down the ice field surface and a very shallow cold air outflow originating from the ice field caving system downstream of the ice field snout.

Numerical analysis of the flow field provided further insight into the potential origin of the katabatic flow over the ice field and its effect on heat exchange processes by driving the magnitude and the spatial distribution of sensible turbulent heat fluxes at the Ice Chapel. During situations when a katabatic flow development in the shaded parts of the surrounding rock face was simulated, a well-developed katabatic flow drained down the ice field, inducing strong turbulent mixing and turbulent sensible heat exchange towards the ice surface. Conversely, numerical results suggest lateral atmospheric decoupling to take place in case of the onset of a shallow katabatic flow directly over the ice field, suppressing heat exchange towards the ice field surface. The augmenting effect on the turbulent heat flux at the central part of the ice field in particular might explain minimum snow ablation evidenced by measurements for this area. These results agree with earlier numerical results on boundary layer development over large snow patches (Mott et al., 2015, 2017), suggesting that the isolation effect of shallow katabatic flows strongly affect the surface energy balance by decoupling the nearsurface atmospheric layer from the adjacent warmer air. Similarly, Shea and Moore (2010) suggested that katabatic flows lower the climatic sensitivity of glaciers to external temperature changes.

This study highlights the importance of accumulation processes and micrometeorology for the survival of very small glaciers and perennial ice fields. The combination of strong snow accumulation in winter and suppression of ice ablation in summer explains the existence of the Ice Chapel at this low elevation until today. The assessment of the relative contribution of accumulation versus ablation processes is difficult. Results suggest that the existence of the ice field is mainly a function of snow deposition by avalanches, but micrometeorological processes changing the local air temperature field are additionally required to attenuate the total mass loss of the ice field observed during the last decades. The isolation effect of shallow katabatic winds might play a crucial role. The survival of the perennial ice field during the next decades will, however, strongly depend on the rising snow line in the future and the sum of snowfall on the Watzmann east face, which is gravitationally redistributed towards the ice field during winter.

We believe that a next important step would be a systematic analysis of the effect of different micrometeorological processes on the local air temperature allowing a parameter- ization for distributed hydrological and energy balance models, similar to what has been done for the effect of katabatic wind systems on the local air temperature over large glaciers and related surface heat fluxes (Quinn et al., 1991; Greuell and Böhm, 1998; Oerlemans and Grisogono, 2002; Petersen et al., 2013). Furthermore, the assessment of the impact of micrometeorological drivers for the sensitivity of very small glaciers to climate change will significantly contribute to an improved assessment of climate change impacts on the distribution of Alpine glaciers in future. These findings will not be limited to Alpine glaciers but will also be transferable to glaciers worldwide.

Data availability. Data used in this paper will be made available upon request to the first author.

Author contributions. RM led the measurement campaign, conducted field measurements, ran the atmospheric model, analysed data, and prepared the paper. AW conducted long-term mass balance measurements at the Ice Chapel and provided data for the publication. MK conducted infrared measurements and post-processed the acquired data. HK supported and supervised the project. M. Warscher conducted field experiments. TG conducted TLS measurements at the Ice Chapel, post-processed data, and helped write the paper.

Competing interests. The authors declare that they have no conflict of interest.

Acknowledgements. The work was funded by Swiss National Science Foundation (project: The sensitivity of very small glaciers to micrometeorology. P300P2_164644), by the Commission for Technology and Innovation CTI (grant 2013.0288), and by the Bavarian State Ministry of the Environment and Consumer Protection (BIAS II: TKP01KPB-66747). We thank Annette Lotz, responsible for research activities in the Berchtesgaden National Park for logistically supporting field experiments in the national park.

Review statement. This paper was edited by Valentina Radic and reviewed by Michael Kuhn and Noel Fitzpatrick.

\section{References}

Ayala, A., Pellicciotti, F., and Shea, J. M.: Modeling $2 \mathrm{~m}$ air temperatures over mountain glaciers: Exploring the influence of katabatic cooling and external warming, J. Geophys. Res.-Atmos. 120, 3139-3157, https://doi.org/10.1002/2015JD023137, 2015.

Bahr, D. B. and Radic, V.: Significant contribution to total mass from very small glaciers, The Cryosphere, 6, 763-770, https://doi.org/10.5194/tc-6-763-2012, 2012. 
Curtis, J. A., Flint, L. E., Flint, A. L., Lundquist, J. D., Hudgens, B., Boydston, E. E., and Young, J. K.: Incorporating Cold-Air Pooling into Downscaled Climate Models Increases Potential Refugia for Snow-Dependent Species within the Sierra Nevada Ecoregion, CA, PLoS ONE, 9, e106984 https://doi.org/10.1371/journal.pone.0106984, 2014.

Dadic, R., Mott, R., Lehning, M., and Burlando, P.: Wind influence on snow depth distribution and accumulation over glaciers, J. Geophys. Res., 115, F01012, https://doi.org/10.1029/2009JF001261, 2010.

Dadic, R., Mott, R., Lehning, M., Carenzo, M., Anderson, B., and Mackintosh, A.: Sensitivity of turbulent fluxes to wind speed over snow surfaces in different climatic settings, Adv. Water Resour., 55, 178-189, https://doi.org/10.1016/j.advwatres.2012.06.010, 2013.

Denby, B.: Second-Order Modelling of Turbulence in Katabatic Flows, Bound.-Lay. Meteorol., 92, 67-100, https://doi.org/10.1023/A:1001796906927, 1999.

Denby, B. and Greuell, W.: The use of bulk and profile methods for determining surface heat fluxes in the presence of glacier winds, J. Glaciol., 46, 445-452, 2000.

Dickich, A. N. and Hagg, W.: Climate driven changes of glacier runoff in the Issyk-Kul basin, Kyrgyzstan, Zeitschrift für Gletscherkunde und Glazialgeologie, 39, 75-86, 2004.

Egli, L., Jonas, T., Grünewald, T., Schirmer, M., and Burlando, P.: Dynamics of snow ablation in a small Alpine catchment observed by repeated terrestrial laser scans, Hydrol. Process., 26, 15741585, 2012.

Escher-Vetter, H.: Zum Gletscherverhalten in den Alpen im zwanzigsten Jahrhundert, in: Klimastatusbericht 2001, Deutscher Wetterdienst, Offenbach, 51-57, 2002.

Essery, R., Granger, R., and Pomeroy, J. W.: Boundary-layer growthand advection of heat over snow and soil patches: modelling andparameterization, Hydrol. Process., 20, 953-967, 2006.

Fujita, K., Hiyama, K., Iida, H., and Ageta, Y.: Selfregulated fluctuations in the ablation of a snow patch over four decades, Water Resour. Res., 46, W11541, https://doi.org/10.1029/2009WR008383, 2010.

Gerber, F., Lehning, M., Hoch, S. W., and Mott, R.: A closeridge small-scale atmospheric flow field and its influence on snow accumulation, J. Geophys. Res.-Atmos., 122, 7737-7754, https://doi.org/10.1002/2016JD026258, 2017.

Gerber, F., Mott, R., and Lehning, M.: The Importance of Near-Surface Winter Precipitation Processes in Complex Alpine Terrain, J. Hydrometeorol., 20, 177-196, https://doi.org/10.1175/JHM-D-18-0055.1, 2019.

Glazirin, G. E.: Distribution and Regime of Mountain Glaciers, Leningrad, Gidrometeoizdat, 179 pp., 1985 (in Russian).

Greuell, W. and Böhm, R.: $2 \mathrm{~m}$ temperatures along melting mid latitude glaciers, and implications for the sensitivity of the mass balance to variations in temperature, J. Glaciol., 146, 9-20, 1998.

Grudzielanek, A. M. and Cermak, J.: Capturing cold-air flow using thermal imaging, Bound.-Lay. Meteorol., 157, 321-332, https://doi.org/10.1007/s10546-015-0042-8, 2015.

Grünewald, T. and Wolfsperger, F.: Water Losses During Technical Snow Production: Results From Field Experiments, Front. Earth Sci., 7, 78, https://doi.org/10.3389/feart.2019.00078, online first, 2019.
Grünewald, T., Schirmer, M., Mott, R., and Lehning, M.: Spatial and temporal variability of snow depth and ablation rates in a small mountain catchment, The Cryosphere, 4, 215-225, https://doi.org/10.5194/tc-4-215-2010, 2010.

Grünewald, T., Wolfsperger, F., and Lehning, M.: Snow farming: conserving snow over the summer season, The Cryosphere, 12, 385-400, https://doi.org/10.5194/tc-12-385-2018, 2018.

Hantel, M., Maurer, C., and Mayer, D.: The snowline climate of the Alps 1961-2010, Theor. Appl. Climatol., 110, 517-537, https://doi.org/10.1007/s00704-012-0688-9, 2012.

Hornauer, W. and Eichner, B.: Bestimmung der Flächen- und Volumenänderung der Eiskapelle am Watzmann, unpublished thesis, Technical University of Munich, Munich, 1997.

Kaser, G., Hardy, D. R., Mölg, T., Bradley, R. S., and Hyera, T. M.: Modern glacier retreat on Kilimanjaro as evidence of climate change: observations and facts, Int. J. Climatol., 24, 329-339, https://doi.org/10.1002/joc.1008, 2004.

Kaser, G., Cogley, J. G., Dyurgerov, M. B., Meier, M. F., and Ohmura, A.: Mass balance of glaciers and ice caps: Consensus estimates for 1961-2004, Geophys. Res. Lett., 33, L19501, https://doi.org/10.1029/2006GL027511, 2006.

Kuhn, M.: The mass balance of very small glaciers, Zeitschrift für Gletscherkunde und Glazialgeologie, 31, 171-179, 1995.

Kuhn, M., Lambrecht, A., Abermann, J., Patzelt, G., and Gross, G.: Austrian Glaciers 1998 and 1969: Area and Volume Changes, Zeitschrift für Gletscherkunde und Glazialgeologie, 43/44, 3107, 2012.

Marsh, P. and Pomeroy, J. W.: Meltwater fluxes at an arctic foresttundra site, Hydrol. Process, 10, 1383-1400, 1996.

Mölg, T., Cullen, N. J., and Kaser, G.: Solar radiation, cloudiness and longwave radiation over low-latitude glaciers: Implications for mass balance modeling, J. Glaciol., 55, 292-302, 2009.

Mott, R., Schirmer, M., Bavay, M., Grünewald, T., and Lehning, M.: Understanding snow-transport processes shaping the mountain snow-cover, The Cryosphere, 4, 545-559, https://doi.org/10.5194/tc-4-545-2010, 2010.

Mott, R., Egli, L., Grünewald, T., Dawes, N., Manes, C., Bavay, M., and Lehning, M.: Micrometeorological processes driving snow ablation in an Alpine catchment, The Cryosphere, 5, 1083-1098, https://doi.org/10.5194/tc-5-1083-2011, 2011.

Mott, R., Gromke, C., Grünewald, T., Lehning, M.: Relative importance of advective heat transport and boundary layer decoupling in the melt dynamics of a patchy snow cover, Adv. Water Resour., 55, 88-97, https://doi.org/10.1016/j.advwatres.2012.03.001, 2013.

Mott, R., Scipion, D. E., Schneebeli, M., Dawes, N., and Lehning, M.: Orographic effects on snow deposition patterns in mountainous terrain, J. Geophys. Res.-Atmos., 119, 1419-1439, https://doi.org/10.1002/2013JD019880, 2014.

Mott, R., Daniels, M., and Lehning, M.: Atmospheric flow development and associated changes in turbulent sensible heat flux over a patchy mountain snow cover, J. Hydrometeorol., 16, 1315-1340, https://doi.org/10.1175/JHM-D-14-0036.1, 2015.

Mott, R., Paterna, E., Horender, S., Crivelli, P., and Lehning, M.: Wind tunnel experiments: cold-air pooling and atmospheric decoupling above a melting snow patch, The Cryosphere, 10, 445458, https://doi.org/10.5194/tc-10-445-2016, 2016.

Mott, R., Schlögl, S., Dirks, L., and Lehning, M.: Impact of Extreme Land Surface Heterogeneity on Micrometeorology 
over Spring Snow Cover, J. Hydrometeorol., 18, 2705-2722, https://doi.org/10.1175/JHM-D-17-0074.1, 2017.

Mott, R., Vionnet, V., and Grünewald, T.: The seasonal Snow Cover Dynamics: Review on Wind-Driven Coupling Processes, Front. Earth Sci., 6, 197, https://doi.org/10.3389/feart.2018.00197, 2018.

Müller, P.: Parametrisierung der Gletscher-Klima-Beziehung für die Praxis: Grundlagen und Beispiele, Mitteilungen der VAW/ETHZ, 228 pp., 1988.

Nicholson, L. I., Prinz, R., Mölg, T., and Kaser, G.: Micrometeorological conditions and surface mass and energy fluxes on Lewis Glacier, Mt Kenya, in relation to other tropical glaciers, The Cryosphere, 7, 1205-1225, https://doi.org/10.5194/tc-7-12052013, 2013.

Oerlemans, J.: Glaciers and Climate Change, Lisse, Balkema, 148 pp., 2001.

Oerlemans, J. and Grisogono, B.: Glacier winds and parameterisation of the related surface heat fluxes, Tellus A, 54, 440-452, https://doi.org/10.1034/j.1600-0870.2002.201398.x, 2002.

Oerlemans, J. and Van Den Broeke, M.: Katabatic flows over ice sheets and glaciers, Tellus A, 54, 440-452, https://doi.org/10.1034/j.1600-0870.2002.201398.x, 2002.

Paul, F., Kääb, A., Maisch, M., Kellenberger, T., and Haeberli, W.: Rapid disintegration of Alpine glaciers observed with satellite data, Geophys. Res. Lett., 31, L21402, https://doi.org/10.1029/2004GL020816, 2004.

Petersen, L., Pellicciotti, F., Juszak, I., Carenzo, M., and Brock, B.: Suitability of a constant air temperature lapse rate over an Alpine glacier: testing the Greuell and Böhm model as an alternative, Ann. Glaciol., 54, 120-130, https://doi.org/10.3189/2013AoG63A477, 2013.

Pohl, S., Garvelmann, J., Wawerla, J., and Weiler, M.: Potential of an innovative low cost sensor network to understand the spatial and temporal dynamics of a mountain snow cover, Water Resour. Res., 50, 2533-2550, https://doi.org/10.1002/2013WR014594, 2014.

Prokop, A., Schirmer, M., Rub, M., Lehning, M., and Stocker, M.: A comparison of measurement methods: Terrestrial laser scanning, tachymetry and snow probing, for the determination of spatial snow depth distribution on slopes, Ann. Glaciol., 49, 210-216, https://doi.org/10.3189/172756408787814726, 2008.

Quinn, P., Chevallier, P., and Planchon, O.: The prediction of hillslope flow paths for distributed hydrological modelling using digital terrain models Hydrol. Process., 5, 59-79, 1991.

Raderschall, N., Lehning, M., and Schär, C.: Finescale modeling of the boundary layer wind field over steep topography, Water Resour. Res., 44, W09425, https://doi.org/10.1029/2007WR006544, 2008.

Radić, V. and Hock, R.: Regionally differentiated contribution of mountain glaciers and ice caps to future sea-level rise, Nat. Geosci., 4, 91-94, https://doi.org/10.1038/ngeo1052, 2011.
Revuelto, J., López-Moreno, J. I., Azorin-Molina, C., and VicenteSerrano, S. M.: Topographic control of snowpack distribution in a small catchment in the central Spanish Pyrenees: intraand inter-annual persistence, The Cryosphere, 8, 1989-2006, https://doi.org/10.5194/tc-8-1989-2014, 2014.

Riegl Laser Measurement Systems GmbH: RiScan Pro: Viewer, Acquisition and Processing Software, Software Description and User's Instructions, Horn, Austria, 2011.

Rödder, T., Braun, L., and Mayer, C.: Accumulation and snow redistribution processes at the Ice Chapel, Berchtesgaden Alps, Zeitschrift für Glaziologie und Glazialgeologie, 42, 3-20, 2010.

Schaffhauser, A., Adams, M., Fromm, R., Jörg, P., Luzi, G., Noferini, L., and Sailer, R.: Remote sensing based retrieval of snow cover properties, Cold Reg. Sci. Technol., 54, 164-175, https://doi.org/10.1016/j.coldregions.2008.07.007, 2008.

Schirmer, M., Wirz, V., Clifton, A., and Lehning, M.: Persistence in intra- 1366 annual snow depth distribution: 1. Measurements and topographic control, Water Resour. Res., 47, W09516, https://doi.org/10.1029/2010WR009426, 2011.

Schlögl, S., Lehning, M., Fierz, C., and Mott R.: Representation of Horizontal Transport Processes in Snowmelt Modeling by Applying a Footprint Approach, Front. Earth Sci., 6, 120, https://doi.org/10.3389/feart.2018.00120, 2018a.

Schlögl, S., Lehning, M., and Mott, R.: How are turbulent sensible heat fluxes and snow melt rates affected by a changing snow cover fraction?, Front. Earth Sci., 6, 154, https://doi.org/10.3389/feart.2018.00154, 2018b.

Shea, J. M. and Moore, R. D.: Prediction of spatially distributed regional-scale fields of air temperature and vapor pressure over mountain glaciers, J. Geophys. Res., 115, D23107, https://doi.org/10.1029/2010JD014351, 2010.

Sommer, C. G., Lehning, M., and Mott, R.: Snow in a Very Steep Rock Face: Accumulation and Redistribution During and After a Snowfall Event, Front. Earth Sci., 3, 73, https://doi.org/10.3389/feart.2015.00073, 2015.

Strasser, U., Corripio, J., Pellicciotti, F., Burlando, P., Brock, B., and Funk, M.: Spatial and temporal variability of meteorological variables at Haut Glacier d'Arolla (Switzerland) during the ablation season 2001: measurements and simulations, J. Geophys. Res., 109, D03103, https://doi.org/10.1029/2003JD003973, 2004.

Warscher, M., Strasser, U., Kraller, G., Marke, T., Franz, H., and Kunstmann H.: Performance of complex snow cover descriptions in a distributed hydrological model system: A case study for the high Alpine terrain of the Berchtesgaden Alps, Water Resour. Res., 49, 2619-2637, https://doi.org/10.1002/wrcr.20219, 2013.

Wolf, A.: Die Eiskapelle am Königssee - ein schmelzendes Naturwunder? 23 Jahre Höhlenforschung im Gletschereis des Nationalpark Berchtesgaden, Untertage Alpin, 2007, 86-88, 2007. 